\title{
Hair Cell Afferent Synapses: Function and Dysfunction
}

\author{
Stuart L. Johnson, ${ }^{1}$ Saaid Safieddine, ${ }^{2,3}$ Mirna Mustapha, ${ }^{1,4}$ and Walter Marcotti ${ }^{1}$ \\ ${ }^{1}$ Department of Biomedical Science, University of Sheffield, Sheffield S10 2TN, United Kingdom \\ ${ }^{2}$ UMRS 1120, Institut Pasteur, Paris, France \\ ${ }^{3}$ Sorbonne Universités, UPMC Université Paris 06, Complexité du Vivant, Paris, France \\ ${ }^{4}$ Department of Otolaryngology-Head \& Neck Surgery, Stanford University, Stanford, California 94035 \\ Correspondence:w.marcotti@sheffield.ac.uk
}

To provide a meaningful representation of the auditory landscape, mammalian cochlear hair cells are optimized to detect sounds over an incredibly broad range of frequencies and intensities with unparalleled accuracy. This ability is largely conferred by specialized ribbon synapses that continuously transmit acoustic information with high fidelity and sub-millisecond precision to the afferent dendrites of the spiral ganglion neurons. To achieve this extraordinary task, ribbon synapses employ a unique combination of molecules and mechanisms that are tailored to sounds of different frequencies. Here we review the current understanding of how the hair cell's presynaptic machinery and its postsynaptic afferent connections are formed, how they mature, and how their function is adapted for an accurate perception of sound.

Censory organs are exquisitely adapted for detecting input from the external environment. They fulfil the challenge of maximizing sensitivity and reliability of signal detection over a wide dynamic range of stimuli that are graded in magnitude. Mammalian cochlear hair cells are the sensory receptors responsible for transducing acoustic stimuli into electrical signals that are relayed to the brain. Sound leads to deflection of the hair cell stereocilia, opening mechanoelectrical transducer (MET) channels situated at their tips (Fig. 1). Cochlear hair cells are sensitive enough to detect sound-induced displacements of their stereocilia down to a fraction of a nanometer with unparalleled temporal precision (in the range of $\mu \mathrm{sec}$ ) from frequencies of only a few tens of $\mathrm{Hz}$ up to $>100 \mathrm{kHz}$ in some species. The specific timing and pattern of these signals provides a precise representation of the auditory landscape, allowing us, for example, to localize sounds in space and to understand speech in a noisy background. Frequency is mainly encoded by the position of a hair cell along the length of the cochlea, an organ within which a tonotopically organized array of sensory receptors produces an output that can be mapped all the way from the periphery to the auditory cortex. In contrast, intensity and timing of the waveform of the sound are largely defined by the firing pattern of the auditory nerve, controlled by

Editors: Guy P. Richardson and Christine Petit

Additional Perspectives on Function and Dysfunction of the Cochlea available at www.perspectivesinmedicine.org

Copyright (C) 2019 Cold Spring Harbor Laboratory Press; all rights reserved; doi: 10.1101/cshperspect.a033175

Cite this article as Cold Spring Harb Perspect Med 2019;9:a033175 
S.L. Johnson et al.

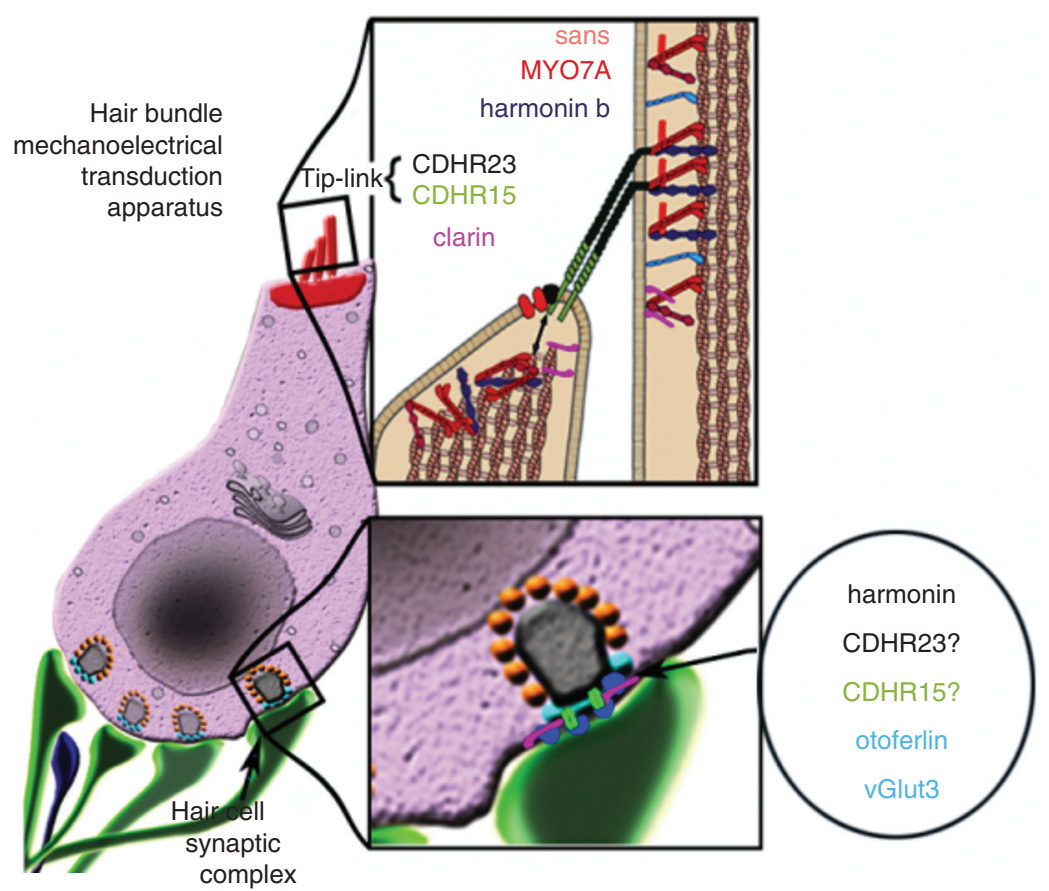

Figure 1. Morphological organization of an inner hair cell (IHC). Hair cell diagram showing the USH1 protein network essential for mechanoelectrical transduction (upper inset). At the synaptic region the protein otoferlin, the glutamate transporter (VGLUT3), clarin, harmonin, CDHR23, and CDHR15 involved in hair cell synaptic transmission (bottom inset). "?", the presence of CDHR23 and CDHR15 at the ribbon synapses is still debatable.

high-fidelity neurotransmitter release at the hair cell ribbon synapses (reviewed by Fuchs 2005).

Adult mammals have two morphologically and functionally distinct types of sensory hair cells that have complementary roles in auditory transduction. A single row of inner hair cells (IHCs) forms the primary sensory structure that relays all of the sound information to type I afferent fibers via the release of glutamate-containing synaptic vesicles. Type I fibers constitute the vast majority of the spiral ganglion neurons (SGNs) that innervate the cochlea ( 95\% [Ryugo 1992]). On the other hand, the three rows of outer hair cells (OHCs) contribute to the wide dynamic range of the mammalian cochlea by enhancing the sensitivity and the frequency tuning properties of the cochlear partition (Dallos 1992). Upon stimulation, OHCs contract and elongate their cylindrical body via the voltage-dependent action of the motor protein prestin (Zheng et al. 2000; Liberman et al. 2002). This somatic electromotility amplifies the vibration of the cochlear basilar membrane and consequently the input to the IHCs, conferring a sharp tuning to their responses around a characteristic sound frequency (for review, see Ashmore 2018). Although mature OHCs are primarily innervated by efferent cholinergic neurons (Liberman 1980; Maison et al. 2003), the role of which is likely to modulate mechanical amplification in the adult cochlea (Guinan 1996), they also receive afferent innervation from type II afferent neurones that make up the remaining $\sim 5 \%$ of SGNs.

The opening of the hair cell MET channels causes the transduction of acoustic information into a receptor potential (for review, see Fettiplace and Kim 2014), which activates L-type $\left(\mathrm{Ca}_{\mathrm{V}} 1.3\right)$ voltage-gated $\mathrm{Ca}^{2+}$ channels located at the presynaptic active zones in the hair cell's basal pole. The resultant $\mathrm{Ca}^{2+}$ entry triggers the fusion of synaptic vesicles, releasing glutamate onto the postsynaptic boutons of SGNs. In cochlear hair cells, synaptic vesicles are tethered to electron-dense organelles called ribbons (Fig. 1). 
This organization, which differs from that of central nervous system (CNS) synapses, seems to be characteristic of sensory cell synapses that respond to sustained and graded stimuli, such as the synapses of vestibular and lateral line hair cells, and of photoreceptors and bipolar neurons in the visual system (Matthews and Fuchs 2010). Because a fraction of the MET channels is normally open in the absence of sound stimulation (Corns et al. 2014a), the resulting inward depolarizing MET current leads to spontaneous release of glutamate at the IHC ribbon synapses (Glowatzki and Fuchs 2002; Grant et al. 2010). The resting neurotransmitter release from a single IHC modulates the rate of spontaneous action potentials (APs) in afferent type I SGNs that display varying thresholds and sensitivity in response to sound.

In cats, each adult IHC is innervated by $5-30$ unbranched type I SGNs that form small contacts or boutons paired with a single presynaptic ribbon (Liberman et al. 1990). In mice and gerbils, the number of IHC ribbon synapses varies tonotopically (between 10 and 20 [Kujawa and Liberman 2009; Meyer et al. 2009]), with fewer contacts in the extreme cochlear apex and base, and higher numbers in the mid-frequency cochlear region, which corresponds to the region that is most sensitive to sounds (i.e., region used for encoding communication signals and vocalization). Synapses on the modiolar side of the IHC generally have larger ribbons and smaller postsynaptic AMPA receptor patches compared to synapses on the pillar cell side (Fig. 2; Liberman et al. 2011). This spatial presynaptic segregation correlates with the morphological and functional diversity of SGNs in terms of their activation thresholds and firing rates (Liberman 1982), the latter being at least partly determined by differences in the properties of glutamate release from IHC ribbon synapses (Grant et al. 2010). In contrast to type I fibers that make synaptic contact with only one IHC, the peripheral terminals of type II afferent SGNs form extensive spiraling arborizations with numerous OHCs (Fig. 3; Perkins and Morest 1975; Echteler 1992), which are only weakly depolarized by ribbon-induced neurotransmitter release from individual OHCs. The function of type II fibers

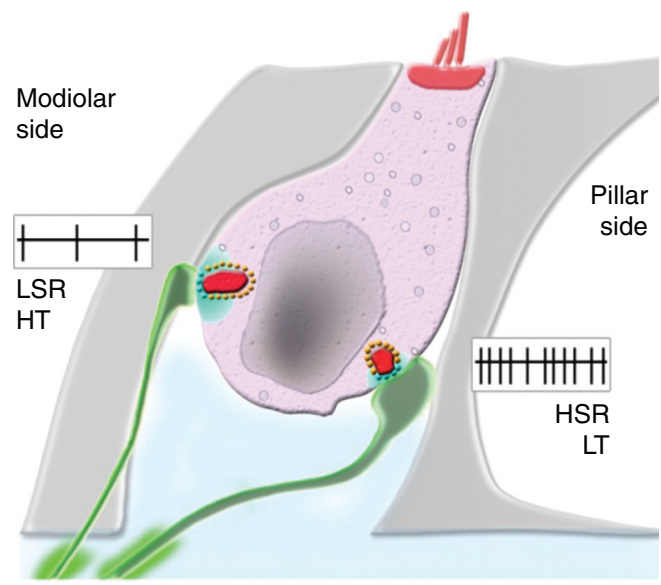

Figure 2. Ribbon synaptic configuration in mature inner hair cells (IHCs). At the IHC modiolar side, presynaptic regions have larger ribbons (red) and display higher $\mathrm{Ca}^{2+}$ inputs (light blue). Afferent neurons have smaller diameters, higher-threshold (HT) sensitivity and lower spontaneous rate (LSR). At the pillar side, ribbons are smaller and $\mathrm{Ca}^{2+}$ influx appears more confined; afferents have larger diameter, lowthreshold (LT) sensitivity, and higher spontaneous rate (HSR). (References for afferent and ribbon characteristics: Liberman 1980 and Liberman et al. 2011; for presynaptic $\mathrm{Ca}^{2+}$ influx: Meyer et al. 2009 and Wong et al. 2014.) (Image reprinted from Safieddine et al. 2012 with permission from Annual Review of Neuroscience (c) 2012.)

is still largely unknown, although they seem to be activated solely by very loud sounds (Robertson 1984; Brown 1994), which led to the assumption that they function as cochlear nociceptors (Weisz et al. 2009; Liu et al. 2015).

In recent years, a considerable effort has been made to identify the proteins and molecular mechanisms underlying the function of hair cell ribbon synapses, using a combination of genetics, biochemistry, and electrophysiology. While there have been numerous advances, the role of the synaptic ribbon remains largely enigmatic, and we lack a detailed understanding of how synaptic vesicle fusion is regulated. Nonetheless, the investigation of the molecular basis of hereditary hearing impairment has provided an ensemble of entry points to understand the molecular physiology of ribbon synapses in mammalian hair cells and their afferent inner- 
S.L. Johnson et al.

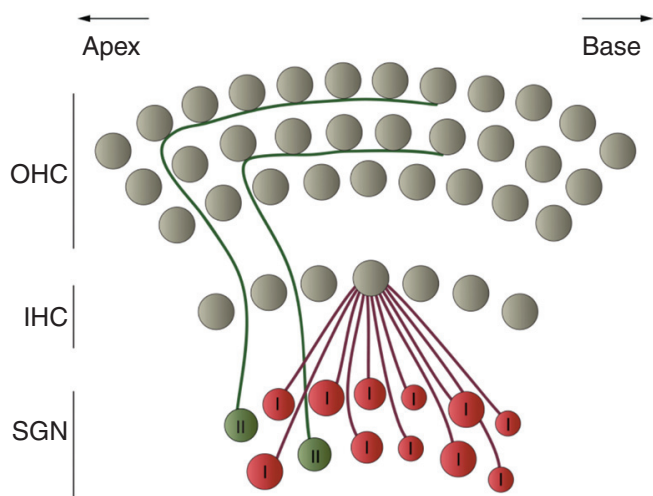

Figure 3. Diagram depicting the innervation inner (IHCs) and outer hair cells (OHCs) by spiral ganglion neurons (SGNs) in the adult cochlea. Illustration of the mature pattern of cochlear afferent innervation. Mature IHCs are innervated by $\sim 95 \%$ of the type I SGN fibers. In mice, about 10-20 unbranched myelinated SGNs connect with a single IHC while each neuron receives input from only one IHC. The remaining $\sim 5 \%$ of SGNs are type II unmyelinated neurons that project toward the OHCs and spiral toward the base of the cochlea contacting multiple OHCs.

vation. The aim of this work is to provide an overview of these advances.

\section{DEVELOPMENT OF MAMMALIAN COCHLEAR HAIR CELL SYNAPSES}

The development of hair cells into functionally mature sensory receptors in mice takes about 3 weeks from their terminal mitosis around embryonic day 12-14 (Anniko 1983; Pujol et al. 1998) until just after the onset of hearing at around postnatal day 12 in various altricial rodents (Ehret 1983; Romand 1983). During this time window, the mechanosensitive hair bundles of both IHCs and OHCs are formed (for reviews, see Corns et al. 2014b; Barr-Gillespie 2015), and their basolateral membrane properties undergo substantial morphological and biophysical alterations (for reviews, see Housley et al. 2006; Marcotti 2012; Corns et al. 2014b; Basch et al. 2016). For these changes to occur, hair cells go through a critical pre-hearing period, which differs between IHCs and OHCs (Fig. 4). Immature hair cells fire spontaneous
$\mathrm{Ca}^{2+}$-dependent action potentials that drive their own maturation (Johnson et al. 2013; Ceriani et al. 2018; Corns et al. 2018) as well as that of the maturing auditory pathway (Clause et al. 2014; Zhang-Hooks et al. 2016; Shrestha et al. 2018; Sun et al. 2018). Therefore, the correct maturation of hair cells and SGN innervation requires the precise timing and integration of genetic programs and physiologically driven electrical activity (Corns et al. 2014b; Delacroix and Malgrange 2015). One of the most crucial steps in the functional maturation of hair cells is the formation and refinement of the highly specialized ribbon synapses (Pujol et al. 1998).

\section{Morphological Changes during the Maturation of Hair Cell Synapses}

Synaptogenesis in mouse IHCs mainly occurs postnatally (Shnerson et al. 1981; Sobkowicz et al. 1992). However, $\mathrm{Ca}^{2+}$ currents and the corresponding $\mathrm{Ca}^{2+}$-induced fusion of vesicles with the presynaptic plasma membrane, which can be assessed by recording changes in cell membrane capacitance $\left(\Delta C_{\mathrm{m}}\right)$, are detectable in IHCs as early as embryonic day 16.5 (E16.5 [Marcotti et al. 2003a; Johnson et al. 2005]). The presynaptic machinery is functional, although very immature, a few days before contacts to type I SGNs are established at around birth (Fig. 4; Sobkowicz et al. 1986; for review, see Safieddine et al. 2012). Postsynaptic densities are observed a few days later (Sobkowicz et al. 1986). At this stage, the peripheral endings of type I SGNs are highly branched and make multiple synaptic contacts with several IHCs and even with OHCs (reviewed by Pujol et al. 1998). Over the next two postnatal weeks, the ribbon synapses undergo major remodeling to fulfil the different functions that IHCs have before and after the onset of hearing (i.e., firing spontaneous APs to generate activity in the immature auditory circuitry before, and then responding to sound with graded receptor potentials). During the first postnatal week, the size of the $\mathrm{Ca}^{2+}$ current rapidly increases, reaching a maximum value around P6$\mathrm{P} 7$, a time when $\mathrm{Ca}^{2+}$ channels are expressed throughout the IHC basolateral membrane (Zampini et al. 2010) and are required to drive 
Hair Cell Afferent Synapses

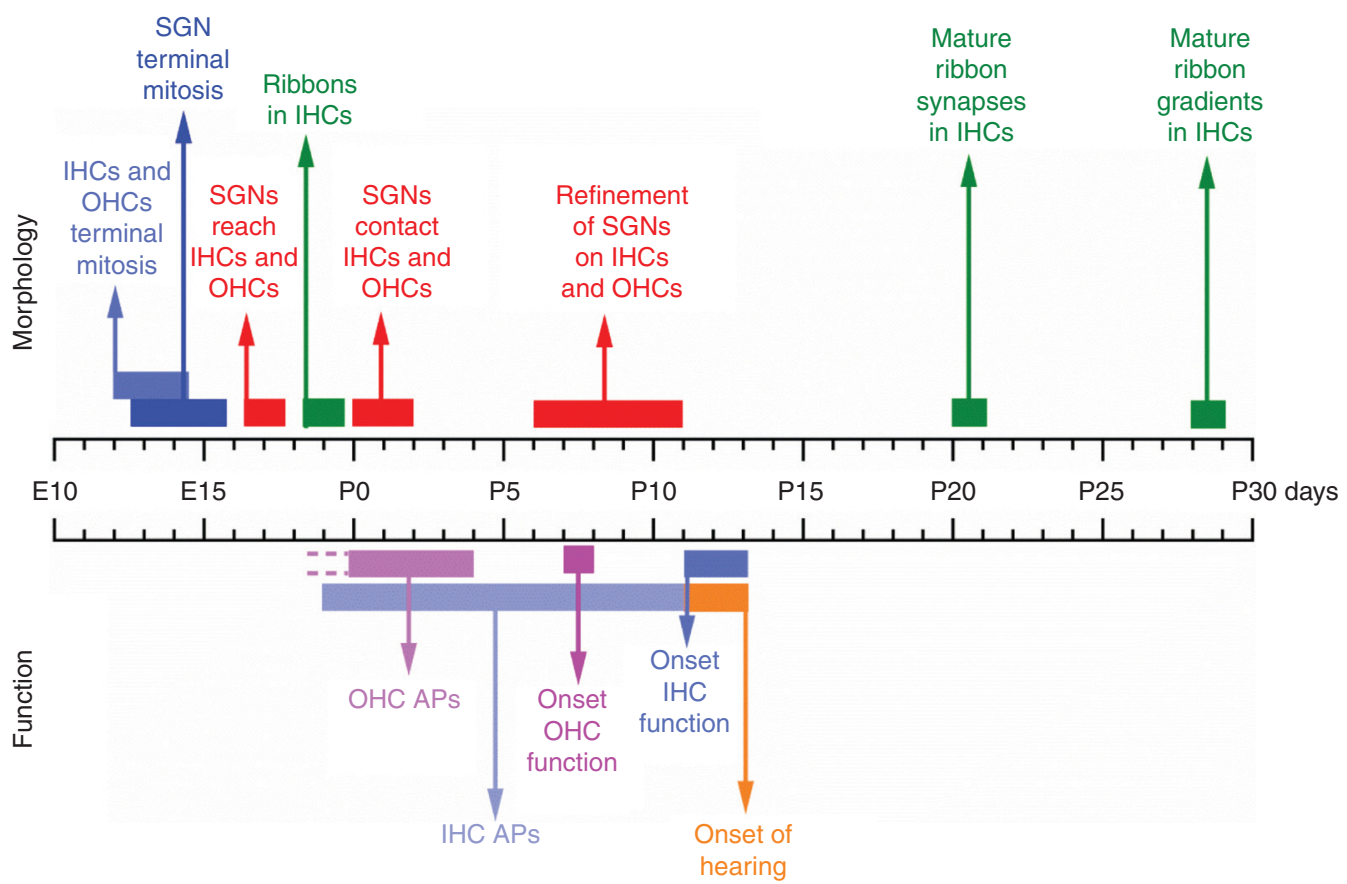

Figure 4. Maturation of the mouse cochlea. Diagram showing the morphological and functional maturation of spiral ganglion neurons (SGNs) and hair cells in the mouse cochlea. References on the morphology part: hair cells terminal mitosis (for review, see Basch et al. 2015); SGNs; terminal mitosis, reaching the hair cell region and their refinement (Koundakjian et al. 2007; Coate and Kelley 2013; Delacroix and Malgrange 2015); ribbon present in inner hair cells (IHCs) (Huang et al. 2012); the maturation of ribbon synapses and the establishment of the gradients within an IHC (Wong et al. 2014; Liberman and Liberman 2016). References on the functional part: spontaneous action potentials in outer hair cells (OHCs) (Ceriani et al. 2018) and IHCs (Kros et al. 1998; Beutner and Moser 2001; Marcotti et al. 2003b; Tritsch et al. 2007; Johnson et al. 2017a), onset of function in OHCs (Marcotti and Kros 1999; Abe et al. 2007) and IHCs (Kros et al. 1998; Marcotti et al. 2003a), and onset of hearing (Ehret 1983; Romand 1983).

the spontaneous $\mathrm{Ca}^{2+}$-dependent AP activity. During the second postnatal week, the $\mathrm{Ca}^{2+}$ current amplitude declines and reaches a constant value of about $100 \mathrm{pA}$ around P12 (Marcotti et al. 2003b; Johnson et al. 2005), which corresponds to the onset of IHC sensory function (Fig. 4 ). During the same period, the number of presynaptic ribbons decreases (Sobkowicz et al. 1986; Sendin et al. 2007; Huang et al. 2012) as a consequence of the pruning of type I SGN branches (for review, see Pujol et al. 1998), such that in the mature cochlea, type I SGNs form one-to-one axosomatic contact with a given IHC (Fig. 3) (Kujawa and Liberman 2009; Meyer et al. 2009; Liberman and Liberman 2016). After the onset of hearing, $\mathrm{Ca}^{2+}$ channels cluster beneath the ribbon within the IHC pre- synaptic active zones, resulting in a tighter spatial coupling between $\mathrm{Ca}^{2+}$ influx and exocytosis at mature synapses (e.g., Wong et al. 2014; Neef et al. 2018). However, recent evidence suggests that very tight coupling is only present in relatively low frequency IHCs (Johnson et al. 2017b).

OHCs are contacted by type II SGNs that begin to acquire their mature innervation pattern from around the end of the first postnatal week (Simmons 1994; Simmons et al. 1996), several days before type I SGNs start to show a mature configuration. During the first postnatal week, type II SGNs make many branched contacts with both IHCs and OHCs, reminiscent of the elaborate branching of type I fibers before P0. They then go through a stage of synaptic pruning, as a result of the death of overabundant 
S.L. Johnson et al.

fibers (Barclay et al. 2011; Sundaresan et al. 2016), to reach the mature configuration with each fiber exclusively innervating between 5 and 30 OHCs (Barclay et al. 2011; Zhang and Coate 2017). This period of refinement is consistent with the reduction in the number of $\mathrm{OHC}$ synaptic ribbons that occurs from around $\mathrm{P} 3$ to the onset of hearing (Huang et al. 2012). OHCs express a small $\mathrm{Ca}^{2+}$ current at birth, which is down-regulated during the first postnatal week (Michna et al. 2003; Knirsch et al. 2007; Beurg et al. 2008), in contrast with the up-regulation seen in IHCs. By the time OHCs begin to show electromotile activity (from P7-P8 [Marcotti and Kros, 1999; Abe et al. 2007]), the size of their $\mathrm{Ca}^{2+}$ current is only about $1 / 10$ th of that observed in IHCs at the same stage (Knirsch et al. 2007). In the mature mouse cochlea, each OHC is innervated by two to three type II SGNs (Berglund and Ryugo 1987) and, therefore, contains only about two or three presynaptic ribbons (Huang et al. 2012; Weisz et al. 2012; Ceriani et al. 2018), which is also about 1/10th of the ribbons present in adult IHCs. This indicates that the few ribbon synapses present in electromotile OHCs are likely to be functional and should contribute in some way to cochlear function, but they appear to be insensitive to sound.

\section{Functional Role of Hair Cell Synapses in the Pre-Hearing Cochlea}

During pre-hearing stages of development, when most synapses are forming, immature hair cells fire spontaneous $\mathrm{Ca}^{2+}$-dependent APs (IHCs [Kros et al. 1998; Beutner and Moser 2001; Marcotti et al. 2003b; Tritsch et al. 2007; Johnson et al. 2011, 2012]; OHCs [Ceriani et al. 2018]). In contrast, functionally mature hair cells do not produce spikes but instead generate graded and sustained receptor potentials (Kros et al. 1998; Marcotti and Kros 1999). In immature IHCs, the frequency and pattern of firing activity can be modulated by extrinsic factors such as the efferent neurotransmitter ACh (Glowatzki and Fuchs 2000; Johnson et al. 2011), and by the release of ATP from nonsensory cells in the greater epithelial ridge ([GER], also known as Kölliker's organ) that synchronizes the firing activity of several neighboring IHCs (Tritsch et al. 2007; Johnson et al. 2011, 2017a; Wang et al. 2015). A similar ATP-dependent mechanism has also been found to synchronize the AP activity of neighboring immature OHCs (Ceriani et al. 2018). The synchronized pattern of APs is relayed to the SGNs and the developing auditory pathway by bursts of discrete $\mathrm{Ca}^{2+}$-induced exocytotic events from the immature ribbon synapses of hair cells, which at this stage differ from those present in mature hair cells (IHCs [Beutner and Moser 2001; Johnson et al. 2005, 2009]; OHCs [Beurg et al. 2008; Johnson et al. 2009]). Although the functional role of APs and induced neurotransmitter release in immature hair cells remains unclear, recent studies have provided compelling evidence for their role in the development and refinement of auditory circuits. The spiking activity of IHCs during the first 2 postnatal weeks plays a crucial role in promoting neuronal survival (Zhang-Hooks et al. 2016), refining the immature tonotopic maps in the different auditory brainstem nuclei (Clause et al. 2014) and in the maturation of the hair cell's ribbon synapses (Johnson et al. 2013). In the latter case, IHC spiking activity promotes the developmental change from a high order to a linear $\mathrm{Ca}^{2+}$-dependence of exocytosis (Johnson et al. 2013). In contrast to IHCs, the spiking activity of immature OHCs is only likely to occur during the first postnatal week and is required for the proper maturation of their ribbon synapses as well as their afferent connectivity (Ceriani et al. 2018).

\section{MECHANISMS OF SYNAPTIC EXOCYTOSIS IN MATURE COCHLEAR HAIR CELLS}

Hair cell ribbon synapses have unique morphological, molecular, and physiological characteristics that distinguish them from conventional synapses and also from other sensory cell ribbon synapses (for reviews, see Safieddine et al. 2012; Wichmann and Moser 2015). These synapses can maintain neurotransmitter release at high rates with a high degree of temporal precision. Calcium-triggered exocytosis at ribbon synapses is characteristic of sensory systems that respond to sustained and graded analogue-like stimuli 
(Matthews and Fuchs 2010). However, the overall synaptic vesicle cycle at ribbon synapses appears to be similar to that at conventional synapses of the CNS in terms of vesicle recycling, trafficking to the active zone, docking to the presynaptic plasma membrane, and priming to render the vesicles release-ready. In mammalian hair cells, vesicle fusion and glutamate release at the active zones is triggered by $\mathrm{Ca}^{2+}$ entry through L-type $\left(\mathrm{Ca}_{\mathrm{v}} 1.3\right)$ voltage-gated $\mathrm{Ca}^{2+}$-channels in response to the depolarizing receptor potential, which is generated by either spontaneous repetitive $\mathrm{Ca}^{2+}$ APs in immature cells or by the opening of the MET channels in response to sounds in mature cells (for review, see Corns et al. 2014 b). Calcium at the presynaptic active zones binds to the hair cell's $\mathrm{Ca}^{2+}$ sensor, otoferlin, and triggers the fusion of glutamate-containing synaptic vesicles with the presynaptic plasma membrane. Glutamate release into the synaptic cleft then activates AMPA receptors present on the terminals of the auditory afferent nerve fibers (Safieddine et al. 2012). Although the overall synaptic vesicle cycle is similar between hair cell and other conventional or ribbon synapses, there are molecular differences, with hair cells employing different mechanisms for rapid and sustained release.

\section{Ribbon Synapses}

The rapid and high-fidelity transfer characteristics at IHC ribbon synapses are essential for sound perception and localization (Fuchs 2005; Glowatzki et al. 2008). Ribbons are electron-dense ovoid-shaped structures anchored to the presynaptic membrane close to the center of the active zone, and able to tether a large number of synaptic vesicles (Sobkowicz et al. 1986). Vesicles tethered near the base of the ribbon and adjacent to the presynaptic membrane are believed to form the readily releasable pool (RRP), while those further away are considered part of the secondary releasable pool (SRP) (Beutner and Moser 2001; Johnson et al. 2005). The characteristics of hair cell ribbon synapses differ depending on the morphological and electrical properties of the afferent fibers. In mature IHCs, each ribbon is juxtaposed to a single postsynaptic type I SGN terminal (Fig. 5). The synapses located on the lateral (i.e., pillar cell) side of the IHC body generally have smaller ribbons and larger postsynaptic glutamate AMPA receptor patches, compared to synapses on the modiolar cell side (Liberman et al. 2011).

In mice, the shape of the ribbon tends to change from roughly spherical at pre-hearing stages to more ellipsoidal/elongated in functionally mature IHCs (Sobkowicz et al. 1982; Khimich et al. 2005; Müller et al. 2005). In the gerbil cochlea, a similar morphological transition only occurs in the IHCs in the basal end (Johnson et al. 2008) that respond to high-frequency sounds ( $\sim 30 \mathrm{kHz}$ [Müller 1996]). In the apical low-frequency cochlear region (below $\sim 1-2$ $\mathrm{kHz}$, which is absent in the mouse [Müller et al. 2005]), there is an approximately spherical shape in the adult gerbil (Johnson et al. 2008). The reason for these differences is unclear, but seems to be related to the different receptor potential characteristics of low- and high-frequency cells, which are phase-locked to the sound waveform itself (phasic response) for the former, and to the much slower intensity modulations of the waveform (tonic response) for the latter (Dallos 1985; Palmer and Russell 1986). These findings also indicate that the ribbon shape is unlikely to be solely correlated with the stage of development.

Hair cell ribbon synapses further differ from conventional CNS synapses in that they do not seem to express neuronal SNARE proteins (Nouvian et al. 2011). Additionally, mature IHCs do not express the classical $\mathrm{Ca}^{2+}$-sensing proteins such as synaptotagmins 1, 2, and 9 (Safieddine and Wenthold 1999; Beurg et al. 2008; Pangršič et al. 2012). Instead, cochlear hair cells express otoferlin as the primary $\mathrm{Ca}^{2+}$ sensor for exocytosis (Roux et al. 2006), which is also involved in other parts of the synaptic vesicle cycle such as in vesicle priming (Michalski et al.2017), vesicle replenishment (Johnson et al. 2010; Pangršič et al. 2010), clathrin-mediated endocytosis (Duncker et al. 2013), and regulating the inactivating component of the $\mathrm{Ca}^{2+}$ current (Vincent et al. 2017). Otoferlin belongs to the ferlin family and is located in the membrane of hair-cell synaptic vesicles. Otoferlin is 
S.L. Johnson et al.
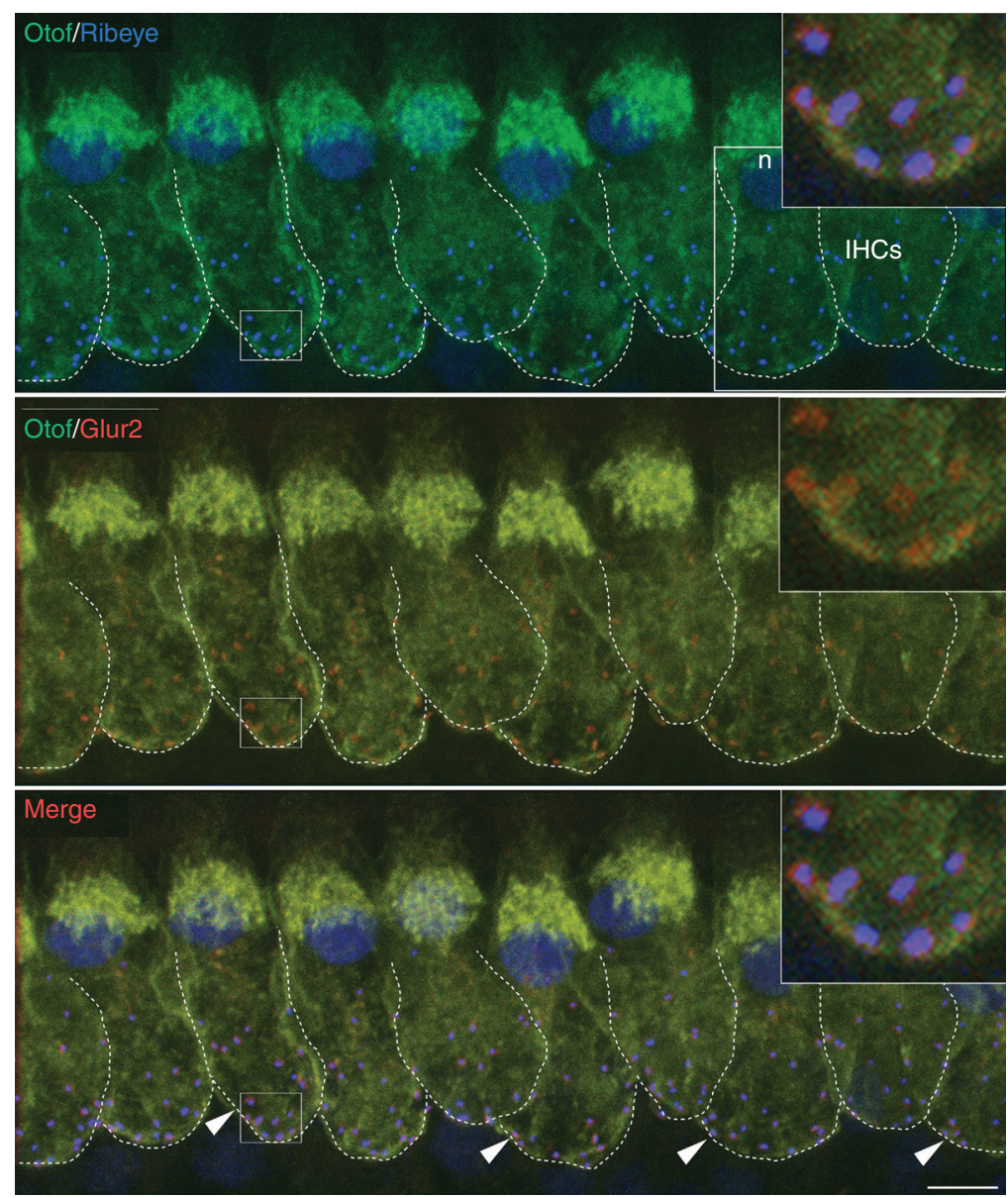

Figure 5. Colocalization between presynaptic ribbons and postsynaptic GluA2 in mature inner hair cells (IHCs). A confocal z-stack projection of IHCs triple-immunostained for otoferlin (green), the ribbon protein RIBEYE (blue), and the GluA2 subunit of postsynaptic AMPA receptors for glutamate (red). At mature IHC synapses, all RIBEYE and GluA2 puncta "co-localize" (arrowheads indicate just a few of them). Dotted lines provide a rough indication of the basolateral membrane around the IHC synaptic region. Note that the RIBEYE antibody also stained the IHC nuclei (n). The insets (top-right corners) are an expanded view of the IHC synaptic region. Scale bar, $5 \mu \mathrm{m}$.

thought to be evolutionarily older than synaptotagmins (Lek et al. 2012) and possesses many synaptotagmin 1-like properties. However, otoferlin and synaptotagmin 1 are not functionally equivalent since neither protein can rescue exocytosis in the absence of the other (Reisinger et al. 2011). One synaptotagmin that is expressed in the mature cochlea is synaptotagmin 4 (Safieddine and Wenthold 1999; Johnson et al. 2010), and has been shown to contribute to the unusual linear $\mathrm{Ca}^{2+}$ dependence of vesicle fusion at mature IHC synapses (Johnson et al. 2010; see also Safieddine et al. 2012).
Even though IHCs do not seem to have neuronal SNAREs, otoferlin has been shown to bind $\mathrm{Ca}^{2+}$ and interact with the t-SNARE proteins syntaxin 1 and SNAP25, as well as with the heterotrimeric form of the syntaxin 1/SNAP25 complex, in a Ca $^{2+}$-dependent manner (Roux et al. 2006; Ramakrishnan et al. 2009; Johnson and Chapman 2010). In addition, otoferlin stimulates SNAREmediated membrane fusion in vitro in the presence of $\mathrm{Ca}^{2+}$ (Johnson and Chapman 2010). Current work is devoted to clarifying these discrepancies with the aim of unveiling the vesicle fusion machinery at IHC ribbon synapses. 
Ribbons are anchored to the presynaptic active zone by the cytomatrix protein bassoon (Khimich et al. 2005). The protein RIBEYE is the major component of synaptic ribbons (Zanazzi and Matthews 2009), including those in mouse cochlear hair cells (Khimich et al. 2005). RIBEYE is composed of one A domain, which has a unique structure and forms the scaffolding of the ribbon, and the B domain that is encoded by the transcriptional corepressor $C t B P 2$ gene, albeit using a different transcription initiation site (Schmitz et al. 2000). The full genetic deletion of Ribeye in the mouse retina abolishes all presynaptic ribbons in bipolar neurons, leading to severe impairment of the rapid and sustained components of neurotransmitter release (Maxeiner et al. 2016). This significant functional impairment showed that RIBEYE plays a crucial role in determining the nanodomain coupling between $\mathrm{Ca}^{2+}$ channels and synaptic vesicle exocytosis at retinal ribbon synapses. However, deletion of RIBEYE from hair cell synapses resulted in only mild hearing loss and subtle changes in the physiology of IHC synapses, suggesting a possible role of the ribbon in synaptic vesicle replenishment (Jean et al. 2018) and/or its action as a biological buffer maintaining a constant number of vesicles at the release site (Becker et al. 2018).

\section{Presynaptic Calcium Channels}

Cochlear hair cells express L-type $\mathrm{Ca}_{\mathrm{v}} 1.3$ voltage-gated $\mathrm{Ca}^{2+}$ channels almost exclusively (>90\% of all $\mathrm{Ca}^{2+}$ channels [Platzer et al. 2000; Michna et al. 2003]), and these channels are directly responsible for the $\mathrm{Ca}^{2+}$ entry that triggers exocytosis at their ribbon synapses (Brandt et al. 2003; Beurg et al. 2008). The $\mathrm{Ca}^{2+}$ channels below hair cell ribbons are not only different from those found at conventional synapses (which are of the $\mathrm{Ca}_{\mathrm{v}} 2$ type), but also differ from those of rod photoreceptor ribbon synapses (of $\mathrm{Ca}_{\mathrm{v}} 1.4$ type) (reviewed by Pangršič et al. 2018). In hair cells, the $\mathrm{Ca}_{\mathrm{v}} 1.3 \mathrm{Ca}^{2+}$ current shows only a small inactivation (e.g., Koschak et al. 2001; Johnson and Marcotti 2008; Johnson et al. 2008; Zampini et al. 2013), which is likely to be driven by the combined expression of the carboxy-terminal $\mathrm{Ca}_{\mathrm{v}} 1.3$ short and long isoforms (Scharinger et al. 2015; Vincent et al. 2017). This slow inactivating component of the $\mathrm{Ca}_{\mathrm{v}} 1.3$ current is required to sustain the continuous release of synaptic vesicles characteristic of graded ribbon synapses (Vincent et al. 2017).

The number of $\mathrm{Ca}^{2+}$ channels per active zone has been estimated, from single-channel and whole-cell recordings, to be between 40 and 180 in both immature (Brandt et al. 2003; Zampini et al. 2010) and mature (Zampini et al. 2013) IHCs. These values are also corroborated by a recent study using 3D-STED nanoscopy in mature mouse IHCs (Neef et al. 2018). Single $\mathrm{Ca}^{2+}$ channels at hair cell synapses exhibit a very short opening latency $(\sim 50 \mu \mathrm{sec})$ at voltages near to the peak of the $\mathrm{Ca}^{2+}$ current (Zampini et al. 2013). This is sufficiently rapid to accurately encode the onset of sound and to support the cycle by cycle phase-locking up to a few $\mathrm{kHz}$ observed in the firing pattern of auditory afferent fibers in mammals (Palmer and Russell 1986). $\mathrm{Ca}_{\mathrm{v}} 1.3 \mathrm{Ca}^{2+}$ channels activate at around $-70 \mathrm{mV}$ (Zampini et al. 2013) and thus are partially active at the expected resting membrane potential in vivo (between -50 and -60 $\mathrm{mV}$ [Palmer and Russell 1986; Johnson 2015]). The resting $\mathrm{Ca}^{2+}$ entry triggers sustained exocytosis from hair cells that drives the background spontaneous firing activity of auditory fibers (Robertson and Paki 2002). The number of $\mathrm{Ca}^{2+}$ channels and their gating properties differs between individual active zones within the same IHC (Frank et al. 2009; Meyer et al. 2009), and is likely to sustain different resting neurotransmitter release rates. This, in turn, could contribute to the different firing thresholds and spontaneous rates seen among type I SGNs.

\section{Spatial Tightening between Synaptic Vesicles and Calcium Channels}

Before the onset of hearing, the synaptic architecture and neuronal wiring patterns in the cochlea undergo substantial activity-dependent refinement. One of the major changes that occurs in the hair cell's synaptic machinery is an increase in the $\mathrm{Ca}^{2+}$ sensitivity of exocytosis. In immature spiking IHCs $\mathrm{Ca}^{2+}$ APs trigger exocy- 
S.L. Johnson et al.

tosis with a low $\mathrm{Ca}^{2+}$ efficiency of release (Beutner and Moser 2001; Johnson et al. 2005). With maturation, as IHCs lose the ability to fire $\mathrm{Ca}^{2+}$ spikes (Kros et al. 1998), extrasynaptic $\mathrm{Ca}^{2+}$ channels are removed leaving channels localized only at the presynaptic active zones, and the ribbons become larger and less numerous (Wong et al. 2014). These changes, together with other morphological and functional refinements, result in a tighter spatial coupling between $\mathrm{Ca}^{2+}$ channels and synaptic vesicles at the active zones, a property crucial for determining the kinetics and $\mathrm{Ca}^{2+}$ efficiency of exocytosis at functionally mature synapses (e.g., Fedchyshyn and Wang 2005; Leão and von Gersdorff 2009; Chen et al. 2015).

After the onset of hearing, the $\mathrm{Ca}^{2+}$ elevation evoked by the opening of a single $\mathrm{Ca}^{2+}$ channel at an individual IHC active zone seems sufficient to elicit a vesicle fusion event (Brandt et al. 2005; Zampini et al. 2013; Wong et al. 2014). For this to be possible, the distance between the channel and the $\mathrm{Ca}^{2+}$ sensor must be very close, likely within $100 \mathrm{~nm}$ (Neher 1998). Such a close, nanometer-scale coupling has been referred to as a "nanodomain" control of exocytosis; it differs from the more distant micrometer-scale, or "microdomain" coupling observed at conventional synapses, where $\mathrm{Ca}^{2+}$ entry through numerous channels is required to trigger vesicle fusion (Neher 1998). These different coupling organizations have also been characterized by the confining effects that $\mathrm{Ca}^{2+}$ buffers, principally BAPTA and EGTA, have on exocytosis. These $\mathrm{Ca}^{2+}$ buffers have similar affinities for $\mathrm{Ca}^{2+}$, but BAPTA has a much higher binding rate constant than EGTA (Naraghi and Neher 1997), which enables it to buffer increases in intracellular $\mathrm{Ca}^{2+}$ much closer to its source (Neher 1998). Therefore, the binding of EGTA to $\mathrm{Ca}^{2+}$ is too slow to block the release of a nanodomain-coupled RRP, even at concentrations in the $\mathrm{mm}$ range. However, EGTA is able to block RRP release when the $\mathrm{Ca}^{2+}$ channels and vesicle release sites are within a microdomain. As a result, EGTA effectively acts as a high-pass temporal filter for $\mathrm{Ca}^{2+}$ (Wang and Augustine 2015).

Recent experiments in mature IHCs have demonstrated that 5-10 mm intracellular EGTA progressively reduced the release of the RRP from the apical to the base of the gerbil cochlea (Fig. 6; Johnson et al. 2017b). Therefore, the spatial coupling between $\mathrm{Ca}^{2+}$ channels and the vesicle fusion machinery changes from a nanodomain configuration in the low-frequency apical regions $(\sim<2 \mathrm{kHz})$ to a microdomain configuration in the high-frequency basal regions ( $\sim 2 \mathrm{kHz}$ ) (Johnson et al. 2017b). These findings are corroborated by postsynaptic recordings from rat type I SGN terminals tuned to sounds in the several $\mathrm{kHz}$ range (Müller 1991), where the fastest component of vesicle release was greatly reduced by $5 \mathrm{~mm}$ EGTA (Goutman and Glowatzki 2007). In the lowest frequency regions of the mammalian cochlea (those tuned below a few $\mathrm{kHz}$ ), the IHC receptor potential has a predominantly phasic component that is phase-locked to the sound frequency and graded in size to the stimulation intensity (Dallos 1985; Cheatham and Dallos 1993). The advantage of having a tight nanodomain coupling in low-frequency IHCs would be to provide the accurate temporal encoding needed for phase-locking (Rose et al. 1967; Li et al. 2014). A feature of phase-locking in type I SGNs that is difficult to reconcile with $\mathrm{Ca}^{2+}$-dependent exocytosis is that its timing is independent of the presynaptic stimulus intensity (i.e., IHC depolarization) (Rose et al. 1967). Some mechanisms have been proposed, including a possible balance between IHC $\mathrm{Ca}^{2+}$ channel facilitation and synaptic depression (Cho et al. 2011; Goutman 2012) and others based on single $\mathrm{Ca}^{2+}$ channel properties (Magistretti et al. 2015). The latter includes the large $\mathrm{Ca}^{2+}$ tail currents elicited upon IHC repolarization, which are faster and larger than the $\mathrm{Ca}^{2+}$ current observed in response to depolarization. Indeed, $\mathrm{Ca}^{2+}$ tail currents have been shown to elicit phase-locked excitatory postsynaptic currents (EPSCs) (Goutman 2012; Graydon et al. 2011). Moreover, the nanodomain $\mathrm{Ca}^{2+}$ channel configuration allows for the synchronized release of multiple vesicles (Graydon et al. 2011), resulting in the large amplitudes of AMPA receptor-mediated EPSCs observed in the IHCs (Glowatzki and Fuchs 2002).

The specialization of low-frequency IHCs for a phase-locked response is also dictated by 

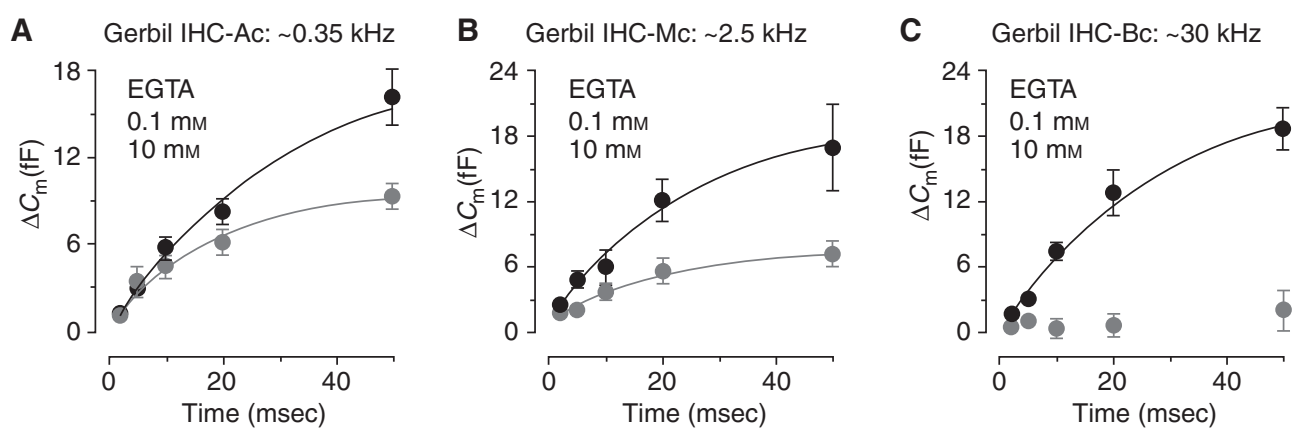

Figure 6. The coupling between $\mathrm{Ca}^{2+}$ entry and exocytosis differs as a function of IHC position along the mature cochlea. $(A-C)$ The kinetics of RRP vesicle pool release in mature gerbil IHCs from apical $(A)$, middle $(B)$, and basal $(C)$ cochlear regions in the presence of $0.1 \mathrm{~mm}$ EGTA (black circles) and $10 \mathrm{~mm}$ EGTA (gray circles). Average $\Delta C_{\mathrm{m}}$ points were obtained in response to voltage steps from 2 to $50 \mathrm{msec}$ (to $-11 \mathrm{mV}$ ) that elicit the release of the RRP. The $x$-axis time refers to the voltage step duration. Note that $10 \mathrm{~mm}$ EGTA blocks RRP release in the basal coil IHCs, reduces it significantly in the middle coil, but only slightly in the apex. (From Fig. 2 in Johnson et al. 2017b; reprinted, with permission, from the Journal of Neuroscience ( $) 2017$.)

their larger resting MET and $\mathrm{K}^{+}$currents, and by a more strongly depolarized resting potential, making their responses to sinusoidal stimulation temporally more precise than in IHCs responding to high-frequency sounds (Johnson 2015). In the high-frequency cochlear regions, the low-pass filtering characteristics of the IHC membrane limit the phase-locking abilities of IHCs to a few $\mathrm{kHz}$. In these regions, IHCs respond instead with graded and sustained receptor potentials to accurately represent modulations in sound intensity represented in the envelope of the waveform (Russell and Sellick 1978). Therefore, high frequency IHCs are not able to follow the frequency components of sound and, as such, do not require the precise timing provided by nanodomain synaptic coupling, other than for signaling the timing of stimulus onset. High-frequency IHCs, instead, seem to be specialized for accurately encoding the wide dynamic range of stimulus intensity (Johnson 2015), where changes in the amplitude and kinetic properties of the macroscopic $\mathrm{Ca}^{2+}$ current, and not through single channels, is what is relevant, a requirement to which a microdomain coupling seems more adapted (Magistretti et al. 2015).

This apparent specialization of high- and low-frequency cells for signaling, respectively, level and timing with accuracy, is likely to relate to the two main strategies used in mammals to localize stimuli of different frequencies. Lowfrequency input is mainly directed to the medial superior olive (MSO) that compares the interaural timing differences (ITDs) of phase-locked activity in SGNs arriving from the two ears (Chirila et al. 2007). High-frequency input is predominantly sent to the lateral superior olive (LSO) that compares interaural level differences (ILDs) arising from the graded responses of IHCs in each ear (Caird and Klinke 1983). Therefore, the accuracy of neuronal phase-locking is a basic requirement for localizing acoustic sources in the low $\mathrm{kHz}$ range, allowing the detection of ITDs as small as $10 \mu \mathrm{sec}$. For high frequency sound stimuli the level differences need to be accurate enough to discriminate ILDs down to as little as 1-2 $\mathrm{dB}$ (Grothe et al. 2010). The phenomenal timing accuracy for low-frequency IHCs and level coding for highfrequency IHCs are likely to be evolutionary specializations driven by the need for survival, predation, and communication. An extreme example of this is in the barn owl, which has an exceptional ability of maintaining phase-locking in auditory neurons for frequencies of up to $\sim 10 \mathrm{kHz}$ (Köppl and Yates 1999).

Based on the experimental evidence discussed above, the idea that the $\mathrm{Ca}^{2+}$ influx-exocytosis coupling tightens with IHC development (Moser and Vogl 2016) is only applicable to lowfrequency IHCs. It seems more likely that this 
S.L. Johnson et al.

hair cell specialization is driven more by the specific frequency-dependent requirements of IHCs in the adult cochlea (Johnson et al. 2017b). It is unknown whether a similar distinction between high and low-frequency $\mathrm{Ca}^{2+}$ coupling configurations also applies to the synapses of $\mathrm{OHCs}$ along the mature cochlea.

\section{Mechanisms Driving Monophasic and Multiphasic EPSCs}

Intracellular patch clamp recordings from type I SGN boutons have shown that vesicle release at IHC ribbon synapses evokes EPSCs of variable amplitude and waveform (Glowatzki and Fuchs 2002; Li et al. 2009; Grant et al. 2010). The majority (>70\%) of EPSCs are "monophasic" showing similar kinetics, with a rapid rise time followed by a slow exponential decay, but have a wide range of peak amplitudes that vary from 30 $\mathrm{pA}$ to about $800 \mathrm{pA}$. The remaining EPSCs are "multiphasic" with multiple peaks and variable rise times and amplitudes. Although the mechanisms driving monophasic and multiphasic EPSCs remain largely unknown, it seems reasonable to consider that they result from varying degrees of synchronization between the fusion of multiple presynaptic vesicles. The largest monophasic EPSCs could, in principle, originate from $>20$ vesicles (Glowatzki and Fuchs 2002).

The very low open probability of $\mathrm{Ca}_{\mathrm{V}} 1.3$ $\mathrm{Ca}^{2+}$ channels in IHCs at rest (Zampini et al. 2010, 2013) makes it unlikely that large monophasic EPSCs could be produced by the simultaneous opening of several $\mathrm{Ca}^{2+}$ channels within a single nanodomain. This suggest that the opening of a single $\mathrm{Ca}^{2+}$ channel could be responsible for triggering the simultaneous fusion of multiple vesicles (Jarsky et al. 2010; Graydon et al. 2011; Magistretti et al. 2015). With IHC depolarization, $\mathrm{Ca}^{2+}$ channels switch to a bursting mode of opening (Zampini et al. 2013), which would increase the fraction of $\mathrm{Ca}^{2+}$ channels that open and the probability (i.e., the reliability) of vesicle fusion (Magistretti et al. 2015). Therefore, bursting $\mathrm{Ca}^{2+}$ channel activity primarily drives vesicle fusion at the IHC presynaptic active zones, and since the number of channels in a bursting-like mode increases with depolarization (Zampini et al. 2013), so does the frequency of EPSCs events, but not the amplitude, which has been shown to be independent of the amount of presynaptic $\mathrm{Ca}^{2+}$ influx (Glowatzki and Fuchs 2002; Grant et al. 2010). A recent computational modeling study proposed that the largest EPSCs correspond to the complete fusion of a single vesicle, while incomplete or flickering fusion events, as well as differences in vesicle volume, are responsible for variablesize monophasic EPSCs (Chapochnikov et al. 2014). Although a third mechanism has been proposed where vesicles pre-fuse to contain varying amounts of neurotransmitter (compound or cumulative vesicle fusion: Matthews and Fuchs 2010), evidence for this in hair cells is lacking.

In a microdomain, which is the expected configuration in high-frequency IHCs, vesicle fusion would reflect the macroscopic $\mathrm{Ca}^{2+}$ current. Since the average open probability of the $\mathrm{Ca}^{2+}$ channels increases with depolarization, the average intracellular $\mathrm{Ca}^{2+}$ concentration would also elevate, at least up to the peak of the currentvoltage relationship for the $\mathrm{Ca}^{2+}$ current (Zampini et al. 2013). In contrast to the nanodomain scenario, it is likely that both the rate (number of vesicles that fuse at different times) and the amplitude (probability that more vesicles fuse at the same time) of EPSCs increases with the $\mathrm{Ca}^{2+}$ summation caused by IHC depolarization. Future work will likely require a combination of electrophysiology and imaging at single synapses to fully understand how IHC ribbon synapses drive EPSCs in SGNs at both low- and high-frequency cochlear regions.

\section{Type I Spiral Ganglion Afferent Fibers}

The fate of mammalian SGNs is specified during early embryonic development from around E9, which is before the final mitosis of the prosensory cells (future hair cells) on E14.5 (Koundakjian et al. 2007). The molecular programs defining SGN identity, as well as the molecules and mechanisms required for their peripheral and central neuronal outgrowth, remain largely unknown (reviewed by Appler and Goodrich 2011; Coate and Kelley 2013; Delacroix and Mal- 
grange 2015). The peripheral axons of type I SGNs make contact with the IHCs from around birth in mice. They show a highly branched pattern at this stage, synapsing with several IHCs and also with OHCs. This initial wiring pattern undergoes progressive pruning or refinement during the first few postnatal days, reaching the characteristic adult-like bipolar neuronal configuration during the second postnatal week. In the mature cochlea, type I SGNs display unbranched peripheral axons that each innervate a single IHC (Fig. 3). In the adult cochlea, each IHC is innervated by several type I SGNs, each neuron forming a single bouton-like contacts juxtaposed to a single presynaptic ribbon (Liberman et al. 1990; Meyer et al. 2009). It is well established that the SGNs innervating a given IHC vary considerably in their thresholds, spontaneous firing rates, and operating ranges (Liberman 1982). Such diversity in type I fiber characteristics is believed to facilitate the accurate temporal and spectral encoding of acoustic stimuli over an extremely wide range (covering 12 orders of magnitude) of sound intensities.

Type I SGNs discharge APs spontaneously in the absence of external sounds (Jones et al. 2007) and can be subdivided based on their spontaneous rate (SR) and threshold, with the latter being the stimulus intensity required to increase the firing rate above the SR. Studies of several mammalian species have shown that the SR is correlated with firing threshold, such that high SR neurons have low thresholds and low SR neurons have high thresholds (Liberman 1982). Single unit in vivo recordings from type I SGN fibers in different mouse strains suggested that, of the fibers innervating each IHC, $49 \%-67 \%$ are low-SR (high threshold) and 33\%-51\% high-SR (low threshold) (Taberner and Liberman 2005). This division into high- and low-SR subpopulations is, however, likely to be an oversimplification considering the wide dynamic range of sound intensities processed by type I SGNs.

Possible tonotopic variations in the above fractions cannot be excluded. Indeed, the intrinsic biophysical properties of type I SGNs are known to vary as a function of their frequency position along the cochlea (Davis and Liu 2011). Therefore, the response properties of the differ- ent type I SGN subgroups is likely to result from the combination of intrinsic biophysical differences in ion channel expression, together with pre- and postsynaptic differences, such as in the size of the presynaptic ribbon and $\mathrm{Ca}^{2+}$ channel distribution (Goutman and Glowatzki 2007; Frank et al. 2009; Meyer et al. 2009; Grant et al. 2010; Davis and Liu 2011; Liberman et al. 2011; Wichmann and Moser 2015). Although the molecular cues involved in specifying a particular type I SGNs subgroup are unknown, a recent study has shown that type I SGN heterogeneity is seeded soon after they make contact with IHCs, since specific molecular markers that differentiate between fiber subgroups become identifiable from around birth (Shrestha et al. 2018). While these molecular markers are present early on, and are therefore independent of IHC input, the final SGN functional diversification seems to depend on presynaptic IHC activity during the first postnatal week. The absence of IHC synaptic activity during development disrupted the relative proportions of each type I subgroup, with low-SR fibers being significantly depleted (Shrestha et al. 2018; Sun et al. 2018). However, another recent study has instead suggested that the acquisition of type I SGN subgroup specification could, in fact, be regulated entirely genetically by intrinsic factors expressed by each SGN and, as such, be independent from IHC-driven activity (Petitpré et al. 2018).

Despite the discrepancies regarding the role of IHC activity in shaping SGN diversity, these studies have contributed to identifying type I SGN subtype-specific molecular signatures. These distinct marker genes can be used in future studies to generate novel transgenic mouse lines to assign specific functions to the different neural subtypes identified. They will also have a direct implication for human health by providing insights into understanding the etiology of noise-induced and age-related hearing impairment, and enabling the development of therapeutic measures that can specifically target fiber subgroups. The ability to direct therapies toward specific neurons seems especially relevant considering recent findings that murine type I SGNs may exhibit differential vulnerability to aging and damage. Studies using single fiber 
S.L. Johnson et al.

recording have shown that there is a selective reduction in the percentage of the low-SR neurons in both noise-exposed and aging rodents, resulting in an auditory synaptopathy type of hearing impairment (Kujawa and Liberman 2015; see also Kohrman et al. 2018). Currently, there is no clear explanation to why low-SR auditory fibers are more affected by noise exposure than the high-SR fibers.

\section{Type II Spiral Ganglion Afferent Fibers}

Adult OHCs are primarily innervated by cholinergic efferent neurons (Liberman 1980; Maison et al. 2003). OHCs also make around 3-5 afferent synaptic contacts with type II SGNs that, in contrast to type I SGNs, are unmyelinated fibers of small caliber and form extensive arborizations with dozens of OHCs (Fig. 3; Perkins and Morest 1975; Echteler 1992; Martinez-Monedero et al. 2016). The role of type II SGNs is still largely unknown, which may be explained by their scarcity (they form $5 \%$ of the SGNs entering the cochlea), but also because they are extremely difficult to identify and record from. Although type II SGNs project to the brain, they appear to be insensitive to acoustic stimulation, adding to the difficulty in characterizing them (Robertson 1984; Brown 1994; Robertson et al. 1999).

In vitro intracellular recordings have demonstrated that type II afferents exhibit very small synaptic potentials (about $4 \mathrm{mV}$ ), and that several OHCs make functional synaptic contact with one type II afferent fiber (Weisz et al. 2009, 2012). For the type II fiber to reach firing threshold (by depolarizing the nerve by about $25 \mathrm{mV}$ ), the simultaneous stimulation of the entire population of $\mathrm{OHCs}$ connected to each fiber was required (Weisz et al. 2014). Morphological studies have also shown the presence of a large number of postsynaptic densities that are not juxtaposed to presynaptic ribbons (MartinezMonedero et al. 2016; Vyas et al. 2017).

Over the years, several roles have been ascribed to type II SGNs (for a recent review, see Fuchs 2018). Based upon the current experimental data, the most likely function seems to be that they are activated solely by trauma (Flo- res et al. 2015; Liu et al. 2015; for a recent review, see Zhang and Coate 2017), leading to the assumption that they function as cochlear nociceptors (Weisz et al. 2009; Liu et al. 2015). OHC damage causes the release of ATP from nearby nonsensory cells, which strongly excites type II fibers (Liu et al. 2015). In agreement with these findings, type II fibers are known to survive cochlear damage (Ryan et al. 1980) and, as such, are ideally suited to signal cochlear trauma to the brain.

\section{PROGRESS IN IDENTIFYING THE GENES ESSENTIAL FOR SYNAPTIC TRANSMISSION IN THE COCHLEA}

Over the past 25 years, the genetics of hearing loss has undergone a complete transformation. Human genetics and the study of mouse models, engineered to carry mutations in a number of genes associated with deafness, have led to a tremendous progress toward understanding the molecular anatomy and physiology of hair cell ribbon synapses. Here, we discuss a number of gene discoveries in families with hereditary hearing loss, all of which have been associated with the elucidation of some of the mechanisms leading to auditory synaptopathy (Fig. 1).

\section{Otoferlin Genetics, Physiology and Pathophysiology}

Otoferlin was originally identified through linkage analysis combined with a candidate gene approach aimed at identifying the molecular basis of hereditary hearing defects, and was found to be defective in DFNB9, a recessive form of human prelingual deafness (Yasunaga et al. 1999; Varga et al. 2006). The human otoferlin gene encodes multiple long and short isoforms, which is due to several alternative splicing and translation initiation sites (Yasunaga and Petit 2000). To date, more than 90 different otoferlin mutations have been reported, most of which result in a severe-to-profound hearing loss, although some mutations are associated with episodic deafness conditioned by fever (Mahdieh et al. 2012). Otoferlin is a carboxy-terminal transmembrane protein containing six $\mathrm{C} 2$ do- 
mains (each consisting of a tandem of fourstranded $\beta$-sheets) that have been involved in $\mathrm{Ca}^{2+}$ and phospholipid binding (Rizo and Südhof 1998). In contrast, the classical $\mathrm{Ca}^{2+}$ sensing synaptotagmins are amino terminal transmembrane proteins containing two $\mathrm{C} 2$ domains. Otoferlin is enriched in the IHC synaptic active zone and was the first molecule identified to be involved in synaptic vesicle exocytosis in auditory hair cells (Roux et al. 2006). This and later studies (Pangršič et al. 2010; Strenzke et al. 2016; Michalski et al. 2017) have revealed a synaptopathy as one of the primary mechanisms leading to human deafness (DFNB9 [Roux et al. 2006]). The similarity in the results of audiological tests between DFNB9 patients and Otof ${ }^{-1}$ mice, together with the extensive pathophysiological analysis conducted on Otof ${ }^{-1-}$ mice, strongly suggest that DFNB9 deafness is indeed caused by a primary defect in synaptic vesicle fusion at the IHC synapse. Moreover, the function of otoferlin as a major presynaptic $\mathrm{Ca}^{2+}$. sensor at the mature IHC synapse was demonstrated in vivo by exploring a knock-in mouse model expressing a modified version of otoferlin wherein the $\mathrm{Ca}^{2+}$-binding property of the $\mathrm{C}_{2} \mathrm{C}$ domain was genetically neutralized (Michalski et al. 2017). These mutant (Otof ${ }^{\mathrm{C} 2 \mathrm{C} / \mathrm{C} 2 \mathrm{C}}$ ) mice have normal hearing thresholds (assessed by auditory brainstem responses [ABRs]), and their IHCs show normal otoferlin expression and ribbon synapse ultrastructure. However, both the fast and the sustained components of IHC exocytosis in these mice displayed a decreased $\mathrm{Ca}^{2+}$. sensitivity despite the IHCs having normal $\mathrm{Ca}^{2+}$-currents. These results led to the conclusion that otoferlin operates as a $\mathrm{Ca}^{2+}$ sensor at the IHC synapse, setting both the rate and the $\mathrm{Ca}^{2+}$ concentration threshold for triggering synaptic vesicle fusion and replenishment (Michalski et al. 2017).

Genetics, Physiology, and Pathophysiology of the Vesicular Glutamate Transporter 3

The normal function of glutamatergic IHC ribbon synapses requires one of the vesicular glutamate transporters (VGLUTs) that are crucial for the refilling of synaptic vesicles with glu- tamate. To date, three VGLUT isoforms, VGLUT1-3, have been identified and functionally characterized in mammals, all of which belong to the family of type I phosphate transporters (also called the SLC17 family) (SánchezMendoza et al. 2017). IHCs express only the VGLUT3 isoform, which is characterized by an unusual distribution (Seal et al. 2008). Mice lacking VGLUT3 (Vglut3 ${ }^{-/-}$mice) are profoundly deaf, but display normal MET currents in response to deflection of the hair bundle. The OHCs and the IHCs of these mice also show normal basolateral membrane biophysical properties of both. However, the afferent boutons of the primary auditory fibers projecting to Vglut $^{-/-}$IHCs do not have synaptic-evoked glutamate receptor currents, indicating a failure of presynaptic glutamate release. In humans, the p.A211V and p.M206Nfs* 4 mutations of the gene encoding VGLUT3 (Slc17a8) are responsible for a progressive hearing loss (DFNA25 [Ruel et al. 2008; Ryu et al. 2016]), linking an auditory synaptopathy to the VGLUT3 defect.

\section{Synaptic Physiology and Pathophysiology of Usher Proteins}

Usher syndrome (USH) is the most frequent cause of deafness associated with blindness, with an estimated incidence of 1 in every 6000 births (Richardson et al. 2011). This syndrome is classified as three types (USH1, USH2, and USH3) according to the severity, the age of the onset of hearing impairment, the presence or absence of a vestibular disorder, and the age of onset of the retinal impairment (with USH1 being the most severe type). Currently, 10 genes whose mutations are responsible for Usher syndrome have been identified. These genes encode proteins with a wide range of functions (Cosgrove and Zallocchi 2014), including two cadherin-related transmembrane proteins (cadherin 23 and protocadherin 15, or CDHR23 and CDHR15, associated with USH1D and USH1F, respectively), two scaffold proteins (harmonin and usherin, associated with USH1C and USH2A, respectively), a G-protein-coupled receptor (ADGRV1, associated with USH2C), and a transmembrane protein from the tetraspa- 
S.L. Johnson et al.

nin family (clarin-1, associated with USH3A). The observation of a common developmental failure of hair cell stereocilia in mouse models harboring mutations in the various genes associated with Usher syndrome, have led to the conclusion that Usher protein function is essential for development and function of stereociliary hair bundles (Boëda et al. 2002; Siemens et al. 2002; El-Amraoui and Petit 2005; Cosgrove and Zallocchi 2014). Interestingly, human genetics and the investigation of mouse models for genes involved in Usher syndrome have uncovered an unexpected role for these proteins in the morphological and functional maturation of the IHC ribbon synapse. For example, harmonin forms a complex with $\mathrm{Ca}_{\mathrm{v}} 1.3 \mathrm{Ca}^{2+}$ channels at the mouse IHC synapse, which enhances their voltage-dependent facilitation and synchronization with exocytosis (Gregory et al. 2011, 2013). In addition, clarin-1, CDHR15, ADGRV1, and specific isoforms of $\mathrm{CDH} 23$ have been shown to form a complex at the IHC ribbon synapse (Zallocchi et al. 2012). Mice lacking any one of the components of this complex, such as clarin-1 or CDHR15, suffer defective synaptic maturation, thus reinforcing the role of Usher proteins at IHC synapses. Finally, the role of clarin-1 in auditory hair cells was recently clarified through the characterization of two knockout mouse models for the protein, one with a total deletion of the gene coding for clarin-1, and another with a conditional deletion of this gene occurring during postnatal stages (Dulon et al. 2018). Comparative morphofunctional analyses of these mice, combined with protein-protein interaction studies showed that clarin-1 is essential for normal auditory hair bundle structure and function, as well as for the function of the presynaptic $\mathrm{Ca}_{\mathrm{v}} 1.3 \mathrm{Ca}^{2+}$ channels at IHC ribbon synapses and, subsequently, for the normal distribution of postsynaptic AMPA receptors.

\section{FINAL REMARKS AND CONCLUSIONS}

Over the last two decades, there have been significant advances in our understanding of how mechanoelectrical transduction at the stereociliary bundle and sensory coding at the ribbon synapses of hair cells are adapted to extract useful information from the acoustic environment. Considerable attention has been given to deciphering the mechanisms underpinning neurotransmitter release at IHC ribbon synapses, which represent the first synapse in the auditory pathway. The properties of this synapse are key to determining how acoustic information is encoded with such speed and high fidelity. Several important proteins have been identified that are specific to ribbon synapses. These include otoferlin, $\mathrm{Ca}_{\mathrm{V}} 1.3 \mathrm{Ca}^{2+}$ channels, RIBEYE, VGLUT3, and are different from those expressed at conventional synapses in the CNS and at other ribbon synapses such as those present in the retina. The unique combination of these proteins, together with their specialized pre- and postsynaptic organization, allow hair cell ribbon synapses to encode information with an unparalleled performance in terms of sustained high rates of vesicle release. We now know that fusion-competent vesicles tethered to the synaptic ribbon are coupled with $\mathrm{Ca}^{2+}$ channels forming either a nanoor a microdomain depending on the frequency range to which IHCs respond. The diversity of the pre- and postsynaptic elements within each hair cell ensures the decomposition of large amounts of acoustic information into manageable components that are represented in real time by the firing activity of equally specialized SGN fibers. Despite these efforts, we are still far from having a comprehensive understanding of the molecular composition and physiology of the hair cell ribbon synapse. For example, the identity of key components of the vesicle fusion machinery is still largely unknown, nor is it clear how $\mathrm{Ca}^{2+}$ regulation at individual synapses affects the different response characteristics of the SGNs. New genetic tools, including transgenic animals, are beginning to be developed and these, in combination with high-resolution optical imaging and possibly in vivo electrophysiological recordings, will address some of the remaining unanswered questions.

\section{ACKNOWLEDGMENTS}

Work in the laboratory of W.M. is supported by the Wellcome Trust (102892); S.S. was supported by the French government funds managed by 
the Agence Nationale de la Recherche. S.L.J. is a Royal Society University Research Fellow. We are thankful to S. Masetto for the careful reading of an earlier draft of this review.

\section{REFERENCES}

${ }^{*}$ Reference is also in this collection.

Abe T, Kakehata S, Kitani R, Maruya S, Navaratnam D, Santos-Sacchi J, Shinkawa H. 2007. Developmental expression of the outer hair cell motor prestin in the mouse. $J$ Membr Biol 215: 49-56. doi:10.1007/s00232-007-9004-5

Anniko M. 1983. Cytodifferentiation of cochlear hair cells. Am J Otolaryngol 4: 375-388. doi:10.1016/S0196-0709 (83)80043-X

Appler JM, Goodrich LV. 2011. Connecting the ear to the brain: Molecular mechanisms of auditory circuit assembly. Prog Neurobiol 93: 488-508. doi:10.1016/j. pneurobio.2011.01.004

* Ashmore J. 2018. Outer hair cells and electromotility. Cold Spring Harb Perspect Med doi:10.1101/cshperspect. a033522

Barclay M, Ryan AF, Housley GD. 2011. Type I vs type II spiral ganglion neurons exhibit differential survival and neuritogenesis during cochlear development. Neural Dev 6: 33. doi:10.1186/1749-8104-6-33

Barr-Gillespie PG. 2015. Assembly of hair bundles, an amazing problem for cell biology. Mol Biol Cell 26: 2727-2732. doi:10.1091/mbc.E14-04-0940

Basch ML, Brown RM II, Jen HI, Groves AK. 2016. Where hearing starts: The development of the mammalian cochlea. J Anat 228: 233-254. doi:10.1111/joa.12314

Becker L, Schnee ME, Niwa M, Sun W, Maxeiner S, Talaei S, Kachar B, Rutherford MA, Ricci AJ. 2018. The presynaptic ribbon maintains vesicle populations at the hair cell afferent fiber synapse. eLife 7: e30241. doi:10.7554/ eLife.30241

Berglund AM, Ryugo DK. 1987. Hair cell innervation by spiral ganglion neurons in the mouse. J Comp Neurol 255: 560-570. doi:10.1002/cne.902550408

Beurg M, Safieddine S, Roux I, Bouleau Y, Petit C, Dulon D. 2008. Calcium- and otoferlin-dependent exocytosis by immature outer hair cells. J Neurosci 28: 1798-1803. doi:10.1523/jneurosci.4653-07.2008

Beutner D, Moser T. 2001. The presynaptic function of mouse cochlear inner hair cells during development of hearing. J Neurosci 21: 4593-4599. doi:10.1523/jneurosci.21-1304593.2001

Boëda B, El-Amraoui A, Bahloul A, Goodyear R, Daviet L, Blanchard S, Perfettini I, Fath KR, Shorte S, Reiners J, et al. 2002. Myosin VIIa, harmonin and cadherin 23, three Usher I gene products that cooperate to shape the sensory hair cell bundle. EMBO J 21: 6689-6699. doi:10.1093/ emboj/cdf689

Brandt A, Striessnig J, Moser T. 2003. $\mathrm{Ca}_{\mathrm{V}} 1.3$ channels are essential for development and presynaptic activity of cochlear inner hair cells. J Neurosci 23: 10832-10840. doi:10.1523/jneurosci.23-34-10832.2003
Brandt A, Khimich D, Moser T. 2005. Few $\mathrm{Ca}_{\mathrm{V}} 1.3$ channels regulate the exocytosis of a synaptic vesicle at the hair cell ribbon synapse. JNeurosci 25: 11577-11585. doi:10.1523/ jneurosci.3411-05.2005

Brown MC. 1994. Antidromic responses of single units from the spiral ganglion. J Neurophysiol 71: 1835-1847. doi:10.1152/jn.1994.71.5.1835

Caird D, Klinke R. 1983. Processing of binaural stimuli by cat superior olivary complex neurons. Exp Brain Res 52: 385399. doi:10.1007/BF00238032

Ceriani F, Hendry A, Jeng JY, Johnson SL, Stephani F, Olt J, Holley MC, Mammano F, Engel J, Kros CJ, et al. 2018. Spontaneous and coordinated $\mathrm{Ca}^{2+}$ activity of cochlear sensory and non-sensory cells drives the maturation of OHC afferent innervation. bioRxiv doi:10.1101/317172

Chapochnikov NM, Takago H, Huang CH, Pangršič T, Khimich D, Neef J, Auge E, Göttfert F, Hell SW, Wichmann C, et al. 2014. Uniquantal release through a dynamic fusion pore is a candidate mechanism of hair cell exocytosis. Neuron 83: 1389-1403. doi:10.1016/j.neuron.2014. 08.003

Cheatham MA, Dallos P. 1993. Longitudinal comparisons of IHC ac and dc receptor potentials recorded from the guinea pig cochlea. Hear Res 68: 107-114. doi:10.1016/ 0378-5955(93)90069-D

Chen Z, Das B, Nakamura Y, DiGregorio DA, Young SM Jr. 2015. $\mathrm{Ca}^{2+}$ channel to synaptic vesicle distance accounts for the readily releasable pool kinetics at a functionally mature auditory synapse. J Neurosci 35: 2083-2100. doi:10.1523/jneurosci.2753-14.2015

Chirila FV, Rowland KC, Thompson JM, Spirou GA. 2007. Development of gerbil medial superior olive: Integration of temporally delayed excitation and inhibition at physiological temperature. J Physiol 584: 167-190. doi:10.1113/ jphysiol.2007.137976

Cho S, Li GL, von Gersdorff H. 2011. Recovery from shortterm depression and facilitation is ultrafast and $\mathrm{Ca}^{2+}$ dependent at auditory hair cell synapses. J Neurosci 31: 5682-5692. doi:10.1523/jneurosci.5453-10.2011

Clause A, Kim G, Sonntag M, Weisz CJ, Vetter DE, Rübsamen R, Kandler K. 2014. The precise temporal pattern of prehearing spontaneous activity is necessary for tonotopic map refinement. Neuron 82: 822-835. doi:10.1016/j.neuron.2014.04.001

Coate TM, Kelley MW. 2013. Making connections in the inner ear: Recent insights into the development of spiral ganglion neurons and their connectivity with sensory hair cells. Semin Cell Dev Biol 24: 460-469. doi:10.1016/ j.semcdb.2013.04.003

Corns LF, Johnson SL, Kros CJ, Marcotti W. 2014a. Calcium entry into stereocilia drives adaptation of the mechanoelectrical transducer current of mammalian cochlear hair cells. Proc Natl Acad Sci 111: 14918-14923. doi:10.1073/ pnas. 1409920111

Corns LF, Bardhan T, Houston O, Olt J, Holley MC, Masetto S, Johnson SL, Marcotti W. 2014b. Functional development of hair cells in the mammalian inner ear. In Development of auditory and vestibular systems (ed. Romand R, Varela-Nieto I), pp. 155-188. Academic, New York.

Corns LF, Johnson SL, Roberts T, Ranatunga KM, Hendry A, Ceriani F, Safieddine S, Steel KP, Forge A, Petit C, et al. 2018. Mechanotransduction is required for establishing 
S.L. Johnson et al.

and maintaining mature inner hair cells and regulating efferent innervation. Nat Commun 9: 4015. doi:10.1038/ s41467-018-06307-w

Cosgrove D, Zallocchi M. 2014. Usher protein functions in hair cells and photoreceptors. Int J Biochem Cell Biol 46: 80-89. doi:10.1016/j.biocel.2013.11.001

Dallos P. 1985. Response characteristics of mammalian cochlear hair cells. J Neurosci 5: 1591-1608. doi:10.1523/ jneurosci.05-06-01591.1985

Dallos P. 1992. The active cochlea. J Neurosci 12: 4575-4585. doi:10.1523/jneurosci.12-12-04575.1992

Davis RL, Liu Q. 2011. Complex primary afferents: What the distribution of electrophysiologically relevant phenotypes within the spiral ganglion tells us about peripheral neural coding. Hear Res 276: 34-43. doi:10.1016/j.heares.2011. 01.014

Delacroix L, Malgrange B. 2015. Cochlear afferent innervation development. Hear Res 330: 157-169. doi:10.1016/ j.heares.2015.07.015

Dulon D, Papal S, Patni P, Cortese M, Vincent PF, Tertrais M, Emptoz A, Tlili A, Bouleau Y, Michel V, et al. 2018. Clarin-1 gene transfer rescues auditory synaptopathy in model of Usher syndrome. J Clin Invest 128: 3382-3401. doi:10.1172/JCI94351

Duncker SV, Franz C, Kuhn S, Schulte U, Campanelli D, Brandt N, Hirt B, Fakler B, Blin N, Ruth P, et al. 2013. Otoferlin couples to clathrin-mediated endocytosis in mature cochlear inner hair cells. J Neurosci 33: 95089519. doi:10.1523/jneurosci.5689-12.2013

Echteler SM. 1992. Developmental segregation in the afferent projections to mammalian auditory hair cells. Proc Natl Acad Sci 89: 6324-6327. doi:10.1073/pnas.89.14. 6324

Ehret G. 1983. Development of hearing and response behavior to sound stimuli: Behavioral studies. In Development of the auditory and vestibular systems (ed. Romand R), pp. 211-237. Academic, New York.

El-Amraoui A, Petit C. 2005. Usher I syndrome: Unravelling the mechanisms that underlie the cohesion of the growing hair bundle in inner ear sensory cells. J Cell Sci 118: 45934603. doi:10.1242/jcs.02636

Fedchyshyn MJ, Wang LY. 2005. Developmental transformation of the release modality at the calyx of Held synapse. J Neurosci 25: 4131-4140. doi:10.1523/ jneurosci.0350-05.2005

Fettiplace R, Kim KX. 2014. The physiology of mechanoelectrical transduction channels in hearing. Physiol Rev 94: 951-986. doi:10.1152/physrev.00038.2013

Flores EN, Duggan A, Madathany T, Hogan AK, Márquez FG, Kumar G, Seal RP, Edwards RH, Liberman MC, García-Añoveros J. 2015. A non-canonical pathway from cochlea to brain signals tissue-damaging noise. Curr Biol 25: 606-612. doi:10.1016/j.cub.2015.01.009

Frank T, Khimich D, Neef A, Moser T. 2009. Mechanisms contributing to synaptic $\mathrm{Ca}^{2+}$ signals and their heterogeneity in hair cells. Proc Natl Acad Sci 106: 4483-4488. doi:10.1073/pnas.0813213106

Fuchs PA. 2005. Time and intensity coding at the hair cell's ribbon synapse. J Physiol 566: 7-12. doi:10.1113/ jphysiol.2004.082214
Fuchs PA. 2018. The diversified form and function of cochlear afferents. In The Oxford handbook of the auditory brainstem (ed. Kandler K). Oxford University Press, Oxford, UK. doi:10.1093/oxfordhb/9780190849061.013.2

Glowatzki E, Fuchs PA. 2000. Cholinergic synaptic inhibition of inner hair cells in the neonatal mammalian cochlea. Science 288: 2366-2368. doi:10.1126/science.288. 5475.2366

Glowatzki E, Fuchs PA. 2002. Transmitter release at the hair cell ribbon synapse. Nat Neurosci 5: 147-154. doi: 10.1038/nn796

Glowatzki E, Grant L, Fuchs PA. 2008. Hair cell afferent synapses. Curr Opin Neurobiol 18: 389-395. doi: 10.1016/j.conb.2008.09.006

Goutman JD. 2012. Transmitter release from cochlear hair cells is phase locked to cyclic stimuli of different intensities and frequencies. J Neurosci 32: 17025-17036. doi: 10.1523/jneurosci.0457-12.2012

Goutman JD, Glowatzki E. 2007. Time course and calcium dependence of transmitter release at a single ribbon synapse. Proc Natl Acad Sci 104: 16341-16346. doi:10.1073/ pnas.0705756104

Grant L, Yi E, Glowatzki E. 2010. Two modes of release shape the postsynaptic response at the inner hair cell ribbon synapse. J Neurosci 30: 4210-4220. doi:10.1523/ jneurosci.4439-09.2010

Graydon CW, Cho S, Li GL, Kachar B, von Gersdorff H. 2011. Sharp $\mathrm{Ca}^{2+}$ nanodomains beneath the ribbon promote highly synchronous multivesicular release at hair cell synapses. J Neurosci 31: 16637-16650. doi:10.1523/ jneurosci.1866-11.2011

Gregory FD, Bryan KE, Pangršič T, Calin-Jageman IE, Moser T, Lee A. 2011. Harmonin inhibits presynaptic Cav1.3 $\mathrm{Ca}^{2+}$ channels in mouse inner hair cells. Nat Neurosci 14: 1109-1111. doi:10.1038/nn.2895

Gregory FD, Pangrsic T, Calin-Jageman IE, Moser T, Lee A. 2013. Harmonin enhances voltage-dependent facilitation of $\mathrm{Ca}_{\mathrm{v}} 1.3$ channels and synchronous exocytosis in mouse inner hair cells. J Physiol 591: 3253-3269. doi:10.1113/ jphysiol.2013.254367

Grothe B, Pecka M, McAlpine D. 2010. Mechanisms of sound localization in mammals. Physiol Rev 90: 9831012. doi:10.1152/physrev.00026.2009

Guinan JJ Jr. 1996. Physiology of olivocochlear efferents. In The cochlea (ed. Dallos P, et al.), pp. 435-502. Springer, New York.

Housley GD, Marcotti W, Navaratnam D, Yamoah EN. 2006. Hair cells-Beyond the transducer. J Membr Biol 209: 89-118. doi:10.1007/s00232-005-0835-7

Huang LC, Barclay M, Lee K, Peter S, Housley GD, Thorne PR, Montgomery JM. 2012. Synaptic profiles during neurite extension, refinement and retraction in the developing cochlea. Neural Dev 7: 38. doi:10.1186/1749-81047-38

Jarsky T, Tian M, Singer JH. 2010. Nanodomain control of exocytosis is responsible for the signaling capability of a retinal ribbon synapse. J Neurosci 30: 11885-11895. doi:10.1523/jneurosci.1415-10.2010

Jean P, Lopez de la Morena D, Michanski S, Jaime Tobón LM, Chakrabarti R, Picher MM, Neef J, Jung S, Gültas M, Maxeiner S, et al. 2018. The synaptic ribbon is critical for 
sound encoding at high rates and with temporal precision. eLife 7: e29275. doi:10.7554/eLife.29275

Johnson SL. 2015. Membrane properties specialize mammalian inner hair cells for frequency or intensity encoding. eLife 4: e08177. doi:10.7554/eLife.08177

Johnson CP, Chapman ER. 2010. Otoferlin is a calcium sensor that directly regulates SNARE-mediated membrane fusion. J Cell Biol 191: 187-197. doi:10.1083/jcb. 201002089

Johnson SL, Marcotti W. 2008. Biophysical properties of $\mathrm{Ca}_{\mathrm{V}} 1.3$ calcium channels in gerbil inner hair cells. J Physiol 586: 1029-1042. doi:10.1113/jphysiol.2007.145219

Johnson SL, Marcotti W, Kros CJ. 2005. Increase in efficiency and reduction in $\mathrm{Ca}^{2+}$ dependence of exocytosis during development of mouse inner hair cells. J Physiol 563: 177191. doi:10.1113/jphysiol.2004.074740

Johnson SL, Forge A, Knipper M, Münkner S, Marcotti W. 2008. Tonotopic variation in the calcium dependence of neurotransmitter release and vesicle pool replenishment at mammalian auditory ribbon synapses. J Neurosci 28: 7670-7678. doi:10.1523/jneurosci.0785-08.2008

Johnson SL, Franz C, Knipper M, Marcotti W. 2009. Functional maturation of the exocytotic machinery at gerbil hair cell ribbon synapses. J Physiol 587: 1715-1726. doi:10.1113/jphysiol.2009.168542

Johnson SL, Franz C, Kuhn S, Furness DN, Ruttiger L, Munkner S, Rivolta MN, Seward EP, Herschman HR, Engel J, et al. 2010. Synaptotagmin IV determines the linear $\mathrm{Ca}^{2+}$ dependence of vesicle fusion at auditory ribbon synapses. Nat Neurosci 13: 45-52. doi:10.1038/ nn. 2456

Johnson SL, Eckrich T, Kuhn S, Zampini V, Franz C, Ranatunga KM, Roberts TP, Masetto S, Knipper M, Kros CJ, Marcotti W. 2011. Position-dependent patterning of spontaneous action potentials in immature cochlear inner hair cells. Nat Neurosci 14: 711-717. doi:10.1038/ nn. 2803

Johnson SL, Kennedy HJ, Holley MC, Fettiplace R, Marcotti W. 2012. The resting transducer current drives spontaneous activity in prehearing mammalian cochlear inner hair cells. J Neurosci 32: 10479-10483. doi:10.1523/ jneurosci.0803-12.2012

Johnson S, Kuhn S, Franz C, Ingham N, Furness DN, Knipper M, Steel KP, Adelman JP, Holley MC, Marcotti W. 2013. Presynaptic maturation in auditory hair cells requires a critical period of sensory-independent spiking activity. Proc Natl Acad Sci 110: 8720-8725. doi:10. 1073/pnas.1219578110

Johnson SL, Ceriani F, Houston O, Polishchuk R, Polishchuk E, Crispino G, Zorzi V, Mammano F, Marcotti W. 2017a. Connexin-mediated signaling in nonsensory cells is crucial for the development of sensory inner hair cells in the mouse cochlea. J Neurosci 37: 258-268. doi:10.1523/ jneurosci.2251-16.2016

Johnson SL, Olt J, Cho S, von Gersdorff H, Marcotti W. 2017b. The coupling between $\mathrm{Ca}^{2+}$ channels and the exocytotic $\mathrm{Ca}^{2+}$ sensor at hair cell ribbon synapses varies tonotopically along the mature cochlea. J Neurosci 37: 2471-2484. doi:10.1523/jneurosci.2867-16.2017

Jones TA, Leake PA, Snyder RL, Stakhovskaya O, Bonham B 2007. Spontaneous discharge patterns in cochlear spiral ganglion cells before the onset of hearing in cats. J Neurophysiol 98: 1898-1908. doi:10.1152/jn.00472.2007

Khimich D, Nouvian R, Pujol R, tom Dieck S, Egner A, Gundelfinger ED, Moser T. 2005. Hair cell synaptic ribbons are essential for synchronous auditory signalling. Nature 434: 889-894. doi:10.1038/nature03418

Knirsch M, Brandt N, Braig C, Kuhn S, Hirt B, Münkner S, Knipper M, Engel J. 2007. Persistence of $\mathrm{Ca}_{\mathrm{v}} 1.3 \mathrm{Ca}^{2+}$ channels in mature outer hair cells supports outer hair cell afferent signaling. J Neurosci 27: 6442-6451. doi: 10.1523/jneurosci.5364-06.2007

* Kohrman D, Wan G, Cassinotti L, Corfas G. 2018. Hidden hearing loss: A disorder with multiple etiologies and mechanisms. Cold Spring Harb Perspect Med doi:10.1101/ cshperspect.a035493

Köppl C, Yates G. 1999. Coding of sound pressure level in the barn owl's auditory nerve. J Neurosci 19: 9674-9686. doi:10.1523/jneurosci.19-21-09674.1999

Koschak A, Reimer D, Huber I, Grabner M, Glossmann H, Engel J, Striessnig J. 2001. $\alpha 1 \mathrm{D}$ (Cav1.3) subunits can form l-type $\mathrm{Ca}^{2+}$ channels activating at negative voltages. J Biol Chem 276: 22100-22106. doi:10.1074/jbc. M101469200

Koundakjian EJ, Appler JL, Goodrich LV. 2007. Auditory neurons make stereotyped wiring decisions before maturation of their targets. J Neurosci 27: 14078-14088. doi: 10.1523/jneurosci.3765-07.2007

Kros CJ, Ruppersberg JP, Rüsch A. 1998. Expression of a potassium current in inner hair cells during development of hearing in mice. Nature 394: 281-284. doi:10.1038/ 28401

Kujawa SG, Liberman MC. 2009. Adding insult to injury: Cochlear nerve degeneration after "temporary" noise-induced hearing loss. J Neurosci 29: 14077-14085.

Kujawa SG, Liberman MC. 2015. Synaptopathy in the noiseexposed and aging cochlea: Primary neural degeneration in acquired sensorineural hearing loss. Hear Res 330: 191-199. doi:10.1016/j.heares.2015.02.009

Leão RM, von Gersdorff H. 2009. Synaptic vesicle pool size, release probability and synaptic depression are sensitive to $\mathrm{Ca}^{2+}$ buffering capacity in the developing rat calyx of Held. Braz J Med Biol Res 42: 94-104. doi:10.1590/S0100879X2009000100014

Lek A, Evesson FJ, Sutton RB, North KN, Cooper ST. 2012. Ferlins: Regulators of vesicle fusion for auditory neurotransmission, receptor trafficking and membrane repair. Traffic 13: 185-194. doi:10.1111/j.1600-0854. 2011.01267.x

Li GL, Keen E, Andor-Ardò D, Hudspeth AJ, von Gersdorff H. 2009. The unitary event underlying multiquantal EPSCs at a hair cell's ribbon synapse. J Neurosci 29: 7558-7568. doi:10.1523/jneurosci.0514-09.2009

Li GL, Cho S, von Gersdorff H. 2014. Phase-locking precision is enhanced by multiquantal release at an auditory hair cell ribbon synapse. Neuron 83: 1404-1417. doi:10.1016/j.neuron.2014.08.027

Liberman MC. 1980. Efferent synapses in the inner hair cell area of the cat cochlea: An electron microscopic study of serial sections. Hear Res 3: 189-204. doi:10.1016/03785955(80)90046-5 
S.L. Johnson et al.

Liberman MC. 1982. Single-neuron labeling in the cat auditory nerve. Science 216: 1239-1241. doi:10.1126/ science. 7079757

Liberman LD, Liberman MC. 2016. Postnatal maturation of auditory-nerve heterogeneity, as seen in spatial gradients of synapse morphology in the inner hair cell area. Hear Res 339: 12-22. doi:10.1016/j.heares.2016.06.002

Liberman MC, Dodds LW, Pierce S. 1990. Afferent and efferent innervation of the cat cochlea: Quantitative analysis with light and electron microscopy. J Comp Neurol 301: 443-460. doi:10.1002/cne.903010309

Liberman MC, Gao J, He DZ, Wu X, Jia S, Zuo J. 2002. Prestin is required for electromotility of the outer hair cell and for the cochlear amplifier. Nature 419: 300304. doi:10.1038/nature01059

Liberman LD, Wang H, Liberman MC. 2011. Opposing gradients of ribbon size and AMPA receptor expression underlie sensitivity differences among cochlearnerve/ hair-cell synapses. J Neurosci 31: 801-808. doi:10.1523/ jneurosci.3389-10.2011

Liu C, Glowatzki E, Fuchs PA. 2015. Unmyelinated type II afferent neurons report cochlear damage. Proc Natl Acad Sci 112: 14723-14727. doi:10.1073/pnas.1515228112

Magistretti J, Spaiardi P, Johnson SL, Masetto S. 2015. Elementary properties of $\mathrm{Ca}^{2+}$ channels and their influence on multivesicular release and phase-locking at auditory hair cell ribbon synapses. Front Cell Neurosci 9: 123. doi:10.3389/fncel.2015.00123

Mahdieh N, Shirkavand A, Rabbani B, Tekin M, Akbari B, Akbari MT, Zeinali S. 2012. Screening of OTOF mutations in Iran: A novel mutation and review. Int J Pediatr Otorhinolaryngol 76: 1610-1615. doi:10.1016/j.ijporl. 2012.07.030

Maison SF, Adams JC, Liberman MC. 2003. Olivocochlear innervation in the mouse: Immunocytochemical maps, crossed versus uncrossed contributions, and transmitter colocalization. J Comp Neurol 455: 406-416. doi:10.1002/ cne. 10490

Marcotti W. 2012. Functional assembly of mammalian cochlear hair cells. Exp Physiol 97: 438-451. doi:10.1113/ exphysiol.2011.059303

Marcotti W, Kros CJ. 1999. Developmental expression of the potassium current $I_{\mathrm{K}, \mathrm{n}}$ contributes to maturation of mouse outer hair cells. J Physiol 520: 653-660. doi: 10.1111/j.1469-7793.1999.00653.x

Marcotti W, Johnson SL, Holley MC, Kros CJ. 2003a. Developmental changes in the expression of potassium currents of embryonic, neonatal and mature mouse inner hair cells. J Physiol 548: 383-400. doi:10.1113/jphysiol. 2002.034801

Marcotti W, Johnson SL, Rüsch A, Kros CJ. 2003b. Sodium and calcium currents shape action potentials in immature mouse inner hair cells. J Physiol 552: 743-761. doi: 10.1113/jphysiol.2003.043612

Martinez-Monedero R, Liu C, Weisz C, Vyas P, Fuchs PA, Glowatzki E. 2016. GluA2-containing AMPA receptors distinguish ribbon-associated from ribbonless afferent contacts on rat cochlear hair cells. eNeuro doi:10.1523/ eneuro.0078-16.2016

Matthews G, Fuchs PA. 2010. The diverse roles of ribbon synapses in sensory neurotransmission. Nat Rev Neurosci 11: $812-822$. doi:10.1038/nrn2924
Maxeiner S, Luo F, Tan A, Schmitz F, Südhof TC. 2016. How to make a synaptic ribbon: RIBEYE deletion abolishes ribbons in retinal synapses and disrupts neurotransmitter release. $E M B O$ J 35: 1098-1114. doi:10.15252/embj. 201592701

Meyer AC, Frank T, Khimich D, Hoch G, Riedel D, Chapochnikov NM, Yarin YM, Harke B, Hell SW, Egner A, et al. 2009. Tuning of synapse number, structure and function in the cochlea. Nat Neurosci 12: 444-453. doi: $10.1038 / \mathrm{nn} .2293$

Michalski N, Goutman JD, Auclair SM, Boutet de Monvel J, Tertrais M, Emptoz A, Parrin A, Nouaille S, Guillon M, Sachse M, et al. 2017. Otoferlin acts as a $\mathrm{Ca}^{2+}$ sensor for vesicle fusion and vesicle pool replenishment at auditory hair cell ribbon synapses. eLife 6: e31013. doi:10.7554/ eLife.31013

Michna M, Knirsch M, Hoda JC, Muenkner S, Langer P, Platzer J, Striessnig J, Engel J. 2003. $\mathrm{Ca}_{\mathrm{v}} 1.3(\alpha 1 \mathrm{D}) \mathrm{Ca}^{2+}$ currents in neonatal outer hair cells of mice. J Physiol 553: 747-758. doi:10.1113/jphysiol.2003.053256

Moser T, Vogl C. 2016. New insights into cochlear sound encoding. F1000Res 5: 2081. doi:10.12688/f1000research. 8924.1

Müller M. 1991. Frequency representation in the rat cochlea. Hear Res 51: 247-254. doi:10.1016/0378-5955(91)90041-7

Müller M. 1996. The cochlear place-frequency map of the adult and developing Mongolian gerbil. Hear Res 94: 148-156. doi:10.1016/0378-5955(95)00230-8

Müller M, von Hünerbein K, Hoidis S, Smolders JW. 2005. A physiological place-frequency map of the cochlea in the CBA/J mouse. Hear Res 202: 63-73. doi:10.1016/j.heares. 2004.08.011

Naraghi M, Neher E. 1997. Linearized buffered $\mathrm{Ca}^{2+}$ diffusion in microdomains and its implications for calculation of $\left[\mathrm{Ca}^{2+}\right]$ at the mouth of a calcium channel. J Neurosci 17: 6961-6973. doi:10.1523/jneurosci.17-18-06961.1997

Neef J, Urban NT, Ohn TL, Frank T, Jean P, Hell SW, Willig KI, Moser T. 2018. Quantitative optical nanophysiology of $\mathrm{Ca}^{2+}$ signaling at inner hair cell active zones. Nat Commun 9: 290. doi:10.1038/s41467-017-02612-y

Neher E. 1998. Vesicle pools and $\mathrm{Ca}^{2+}$ microdomains: New tools for understanding their roles in neurotransmitter release. Neuron 20: 389-399. doi:10.1016/S0896-6273 (00)80983-6

Nouvian R, Neef J, Bulankina AV, Reisinger E, Pangršič T, Frank T, Sikorra S, Brose N, Binz T, Moser T. 2011. Exocytosis at the hair cell ribbon synapse apparently operates without neuronal SNARE proteins. Nat Neurosci 14: 411413. doi: $10.1038 / \mathrm{nn} .2774$

Palmer AR, Russell IJ. 1986. Phase-locking in the cochlear nerve of the guinea-pig and its relation to the receptor potential of inner hair-cells. Hear Res 24: 1-15. doi:10.1016/0378-5955(86)90002-X

Pangršič T, Lasarow L, Reuter K, Takago H, Schwander M, Riedel D, Frank T, Tarantino LM, Bailey JS, Strenzke N, et al. 2010. Hearing requires otoferlin-dependent efficient replenishment of synaptic vesicles in hair cells. $\mathrm{Nat} \mathrm{Neu-}$ rosci 13: 869-876. doi:10.1038/nn.2578

Pangršič T, Reisinger E, Moser T. 2012. Otoferlin: A multiC2 domain protein essential for hearing. Trends Neurosci 35: 671-680. doi:10.1016/j.tins.2012.08.002 
Pangršič T, Singer JH, Koschak A. 2018. Voltage-gated calcium channels: Key players in sensory coding in the retina and the inner ear. Physiol Rev 98: 2063-2096. doi:10.1152/physrev.00030.2017

Perkins RE, Morest DK. 1975. A study of cochlear innervation patterns in cats and rats with the Golgi method and Nomarski optics. J Comp Neurol 163: 129-158. doi: 10.1002/cne.901630202

Petitpré C, Wu H, Sharma A, Tokarska A, Fontanet P, Wang Y, Helmbacher F, Yackle K, Silberberg G, Hadjab S, et al. 2018. Neuronal heterogeneity and stereotyped connectivity in the auditory afferent system. Nat Commun 9: 3691. doi:10.1038/s41467-018-06033-3

Platzer J, Engel J, Schrott-Fischer A, Stephan K, Bova S, Chen H, Zheng H, Striessnig J. 2000. Congenital deafness and sinoatrial node dysfunction in mice lacking class D L-type $\mathrm{Ca}^{2+}$ channels. Cell 102: 89-97. doi:10.1016/S0092-8674 (00)00013-1

Pujol R, Lavigne-Rebillard M, Lenoir M. 1998. Development of sensory and neural structures in the mammalian cochlea. In Development of the auditory system (ed. Rubel EW, et al.), pp. 145-192. Springer, New York.

Ramakrishnan NA, Drescher MJ, Drescher DG. 2009. Direct interaction of otoferlin with syntaxin 1A, SNAP-25, and the L-type voltage-gated calcium channel $\mathrm{Ca}_{\mathrm{v}} 1.3$. J Biol Chem 284: 1364-1372. doi:10.1074/jbc.M803605200

Reisinger E, Bresee C, Neef J, Nair R, Reuter K, Bulankina A, Nouvian R, Koch M, Bückers J, Kastrup L, et al. 2011. Probing the functional equivalence of otoferlin and synaptotagmin 1 in exocytosis. J Neurosci 31: 4886-4895. doi:10.1523/jneurosci.5122-10.2011

Richardson GP, de Monvel JB, Petit C. 2011. How the genetics of deafness illuminates auditory physiology. Annu Rev Physiol 73: 311-334. doi:10.1146/annurev-physiol012110-142228

Rizo J, Südhof TC. 1998. C C $_{2}$-domains, structure and function of a universal $\mathrm{Ca}^{2+}$-binding domain. J Biol Chem 273: 15879-15882. doi:10.1074/jbc.273.26.15879

Robertson D. 1984. Horseradish peroxidase injection of physiologically characterized afferent and efferent neurones in the guinea pig spiral ganglion. Hear Res 15: 113-121. doi:10.1016/0378-5955(84)90042-X

Robertson D, Paki B. 2002. Role of L-type $\mathrm{Ca}^{2+}$ channels in transmitter release from mammalian inner hair cells. II: Single-neuron activity. J Neurophysiol 87: 2734-2740. doi:10.1152/jn.2002.87.6.2734

Robertson D, Sellick PM, Patuzzi R. 1999. The continuing search for outer hair cell afferents in the guinea pig spiral ganglion. Hear Res 136: 151-158. doi:10.1016/S03785955(99)00120-3

Romand R. 1983. Development of the cochlea. In Development of the auditory and vestibular systems (ed. Romand R), pp. 47-88. Academic, New York.

Rose JE, Brugge JF, Anderson DJ, Hind JE. 1967. Phaselocked response to low-frequency tones in single auditory nerve fibers of the squirrel monkey. J Neurophysiol 30: 769-793. doi:10.1152/jn.1967.30.4.769

Roux I, Safieddine S, Nouvian R, Grati M, Simmler MC, Bahloul A, Perfettini I, Le Gall M, Rostaing P, Hamard G, et al. 2006. Otoferlin, defective in a human deafness form, is essential for exocytosis at the auditory ribbon synapse. Cell 127: 277-289. doi:10.1016/j.cell.2006.08. 040

Ruel J, Emery S, Nouvian R, Bersot T, Amilhon B, Van Rybroek JM, Rebillard G, Lenoir M, Eybalin M, Delprat $\mathrm{B}$, et al. 2008. Impairment of SLC17A8 encoding vesicular glutamate transporter-3, VGLUT3, underlies nonsyndromic deafness DFNA25 and inner hair cell dysfunction in null mice. Am J Hum Genet 83: 278-292. doi:10.1016/ j.ajhg.2008.07.008

Russell IJ, Sellick PM. 1978. Intracellular studies of hair cells in the mammalian cochlea. J Physiol 284: 261-290. doi:10.1113/jphysiol.1978.sp012540

Ryan AF, Woolf NK, Bone RC. 1980. Ultrastructural correlates of selective outer hair cell destruction following kanamycin intoxication in the chinchilla. Hear Res 3: 335-351. doi:10.1016/0378-5955(80)90027-1

Ryu N, Sagong B, Park HJ, Kim MA, Lee KY, Choi JY, Kim UK. 2016. Screening of the SLC17A8 gene as a causative factor for autosomal dominant non-syndromic hearing loss in Koreans. BMC Med Genet 17: 6. doi:10.1186/ s12881-016-0269-3

Ryugo DK. 1992. The auditory nerve: Peripheral innervation, cell body morphology, and central projections. In The mammalian auditory pathway: Neuroanatomy (ed. Webster DB, et al.), pp. 23-65. Springer, New York.

Safieddine S, Wenthold RJ. 1999. SNARE complex at the ribbon synapses of cochlear hair cells: Analysis of synaptic vesicle- and synaptic membrane-associated proteins. Eur J Neurosci 11: 803-812. doi:10.1046/j.1460-9568.1999. 00487.x

Safieddine S, El-Amraoui A, Petit C. 2012. The auditory hair cell ribbon synapse: From assembly to function. Annu Rev Neurosci 35: 509-528. doi:10.1146/annurevneuro-061010-113705

Sánchez-Mendoza EH, Bellver-Landete V, Arce C, Doeppner TR, Hermann DM, Oset-Gasque MJ. 2017. Vesicular glutamate transporters play a role in neuronal differentiation of cultured SVZ-derived neural precursor cells. PLOS ONE 12: e0177069. doi:10.1371/journal. pone. 0177069

Scharinger A, Eckrich S, Vandael DH, Schönig K, Koschak A, Hecker D, Kaur G, Lee A, Sah A, Bartsch D, et al. 2015. Cell-type-specific tuning of Cav1.3 $\mathrm{Ca}^{2+}$-channels by a C-terminal automodulatory domain. Front Cell Neurosci 9: 309. doi:10.3389/fncel.2015.00309

Schmitz F, Königstorfer A, Südhof TC. 2000. RIBEYE, a component of synaptic ribbons: A protein's journey through evolution provides insight into synaptic ribbon function. Neuron 28: 857-872. doi:10.1016/S0896-6273 (00)00159-8

Seal RP, Akil O, Yi E, Weber CM, Grant L, Yoo J, Clause A, Kandler K, Noebels JL, Glowatzki E, et al. 2008. Sensorineural deafness and seizures in mice lacking vesicular glutamate transporter 3. Neuron 57: 263-275. doi:10.1016/j.neuron.2007.11.032

Sendin G, Bulankina AV, Riedel D, Moser T. 2007. Maturation of ribbon synapses in hair cells is driven by thyroid hormone. J Neurosci 27: 3163-3173. doi:10.1523/ jneurosci.3974-06.2007

Shnerson A, Devigne C, Pujol R. 1981. Age-related changes in the C57BL/6J mouse cochlea. II: Ultrastructural find- 
S.L. Johnson et al.

ings. Dev Brain Res 2: 77-88. doi:10.1016/0165-3806(81) 90060-2

Shrestha BR, Chia C, Wu L, Kujawa SG, Liberman MC Goodrich LV. 2018. Sensory neuron diversity in the inner ear is shaped by activity. Cell 174: 1229-1246.e17. doi:10.1016/j.cell.2018.07.007

Siemens J, Kazmierczak P, Reynolds A, Sticker M, Littlewood-Evans A, Müller U. 2002. The Usher syndrome proteins cadherin 23 and harmonin form a complex by means of PDZ-domain interactions. Proc Natl Acad Sci 99: 14946-14951. doi:10.1073/pnas.232579599

Simmons DD. 1994. A transient afferent innervation of outer hair cells in the postnatal cochlea. Neuroreport 5: 13091312 .

Simmons DD, Mansdorf NB, Kim JH. 1996. Olivocochlear innervation of inner and outer hair cells during postnatal maturation: Evidence for a waiting period. J Comp Neurol 370: 551-562. doi:10.1002/(SICI)1096-9861(19960708) 370:4<551::AID-CNE10>3.0.CO;2-M

Sobkowicz HM. 1992. The development of innervation in the organ of Corti. In Development of auditory and vestibular systems (ed. Romand R), pp. 59-100. Elsevier, Amsterdam.

Sobkowicz HM, Rose JE, Scott GE, Slapnick SM. 1982. Ribbon synapses in the developing intact and cultured organ of Corti in the mouse. J Neurosci 2: 942-957. doi:10.1523/ jneurosci.02-07-00942.1982

Sobkowicz HM, Rose JE, Scott GL, Levenick CV. 1986 Distribution of synaptic ribbons in the developing organ of Corti. J Neurocytol 15: 693-714. doi:10.1007/ BF01625188

Strenzke N, Chakrabarti R, Al-Moyed H, Müller A, Hoch G, Pangrsic T, Yamanbaeva G, Lenz C, Pan KT, Auge E, et al. 2016. Hair cell synaptic dysfunction, auditory fatigue and thermal sensitivity in otoferlin Ile515Thr mutants. EMBO J 35: 2519-2535. doi:10.15252/embj. 201694564

Sun S, Babola T, Pregernig G, So KS, Nguyen M, Su SM, Palermo AT, Bergles DE, Burns JC, Müller U. 2018. Hair cell mechanotransduction regulates spontaneous activity and spiral ganglion subtype specification in the auditory system. Cell 174: 1247-1263.e15. doi:10.1016/ j.cell.2018.07.008

Sundaresan S, Balasubbu S, Mustapha M. 2016. Thyroid hormone is required for the pruning of afferent type II spiral ganglion neurons in the mouse cochlea. Neuroscience 312: 165-178. doi:10.1016/j.neuroscience.2015. 11.020

Taberner AM, Liberman MC. 2005. Response properties of single auditory nerve fibers in the mouse. J Neurophysiol 93: 557-569. doi:10.1152/jn.00574.2004

Tritsch NX, Yi E, Gale JE, Glowatzki E, Bergles DE. 2007. The origin of spontaneous activity in the developing auditory system. Nature 450: 50-55. doi:10.1038/ nature 06233

Varga R, Avenarius MR, Kelley PM, Keats BJ, Berlin CI, Hood LJ, Morlet TG, Brashears SM, Starr A, Cohn ES, et al. 2006. OTOF mutations revealed by genetic analysis of hearing loss families including a potential temperature sensitive auditory neuropathy allele. J Med Genet 43: 576581. doi:10.1136/jmg.2005.038612
Vincent PF, Bouleau Y, Petit C, Dulon D. 2015. A synaptic F-actin network controls otoferlin-dependent exocytosis in auditory inner hair cells. eLife 4: e10988. doi:10.7554/ eLife.10988

Vincent PF, Bouleau Y, Charpentier G, Emptoz A, Safieddine S, Petit C, Dulon D. 2017. Different $\mathrm{Ca}_{\mathrm{V}} 1.3$ channel isoforms control distinct components of the synaptic vesicle cycle in auditory inner hair cells. J Neurosci 37: 29602975.

Vyas P, Wu JS, Zimmerman A, Fuchs P, Glowatzki E. 2017. Tyrosine hydroxylase expression in type II cochlear afferents in mice. J Assoc Res Otolaryngol 18: 139-151.

Wang LY, Augustine GJ. 2015. Presynaptic nanodomains: A tale of two synapses. Front Cell Neurosci 8: 455.

Wang HC, Lin CC, Cheung R, Zhang-Hooks Y, Agarwal A, Ellis-Davies G, Rock J, Bergles DE. 2015. Spontaneous activity of cochlear hair cells triggered by fluid secretion mechanism in adjacent support cells. Cell 163: 13481359. doi:10.1016/j.cell.2015.10.070

Weisz C, Glowatzki E, Fuchs P. 2009. The postsynaptic function of type II cochlear afferents. Nature 461: 1126-1129. doi:10.1038/nature 08487

Weisz CJ, Lehar M, Hiel H, Glowatzki E, Fuchs PA. 2012. Synaptic transfer from outer hair cells to type II afferent fibers in the rat cochlea. J Neurosci 32: 9528-9536. doi:10.1523/jneurosci.6194-11.2012

Weisz CJ, Glowatzki E, Fuchs PA. 2014. Excitability of type II cochlear afferents. J Neurosci 34: 2365-2373. doi:10.1523/ jneurosci.3428-13.2014

Wichmann C, Moser T. 2015. Relating structure and function of inner hair cell ribbon synapses. Cell Tissue Research 361: 95-114. doi:10.1007/s00441-014-2102-7

Wong AB, Rutherford MA, Gabrielaitis M, Pangrsic T, Göttfert F, Frank T, Michanski S, Hell S, Wolf F, Wichmann C, et al. 2014. Developmental refinement of hair cell synapses tightens the coupling of $\mathrm{Ca}^{2+}$ influx to exocytosis. EMBO J 33: 247-264.

Yasunaga S, Petit C. 2000. Physical map of the region surrounding the OTOFERLIN locus on chromosome 2p22-p23. Genomics 66: 110-112. doi:10.1006/geno. 2000.6185

Yasunaga S, Grati M, Cohen-Salmon M, El-Amraoui A, Mustapha M, Salem N, El-Zir E, Loiselet J, Petit C. 1999. A mutation in OTOF, encoding otoferlin, a FER1-like protein, causes DFNB9, a nonsyndromic form of deafness. Nat Genet 21: 363-369. doi:10.1038/7693

Zallocchi M, Meehan DT, Delimont D, Rutledge J, Gratton MA, Flannery J, Cosgrove D. 2012. Role for a novel Usher protein complex in hair cell synaptic maturation. PLoS ONE 7: e30573. doi:10.1371/journal.pone. 0030573

Zampini V, Johnson SL, Franz C, Lawrence ND, Münkner S, Engel J, Knipper M, Magistretti J, Masetto S, Marcotti W. 2010. Elementary properties of $\mathrm{Ca}_{\mathrm{V}} 1.3 \mathrm{Ca}^{2+}$ channels expressed in mouse cochlear inner hair cells. J Physiol 588: 187-199. doi:10.1113/jphysiol.2009.181917

Zampini V, Franz C, Magistretti J, Johnson SL, Knipper M, Masetto S, Marcotti W. 2013. Burst activity and ultrafast activation kinetics of $\mathrm{Ca}_{\mathrm{V}} 1.3 \mathrm{Ca}^{2+}$ channels support presynaptic activity in adult gerbil hair cell ribbon synapses. J Physiol 591: 3811-3820. doi:10.1113/jphysiol.2013. 251272 
Zanazzi G, Matthews G. 2009. The molecular architecture of ribbon presynaptic terminals. Mol Neurobiol 39: 130148. doi:10.1007/s12035-009-8058-Z

Zhang KD, Coate TM. 2017. Recent advances in the development and function of type II spiral ganglion neurons in the mammalian inner ear. Semin Cell Dev Biol 65: 80-87. doi:10.1016/j.semcdb.2016.09.017
Zhang-Hooks Y, Agarwal A, Mishina M, Bergles DE. 2016. NMDA receptors enhance spontaneous activity and promote neuronal survival in the developing cochlea. Neuron 89: 337-350. doi:10.1016/j.neuron.2015. 12.016

Zheng J, Shen W, He DZ, Long KB, Madison LD, Dallos P. 2000. Prestin is the motor protein of cochlear outer hair cells. Nature 405: 149-155. doi:10.1038/35012009 


\section{$\& \mathrm{CSH} \&$ Cold Spring Harbor

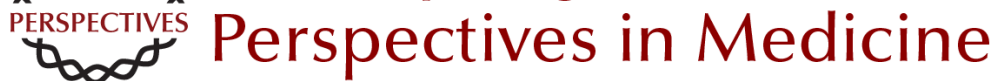

\section{Hair Cell Afferent Synapses: Function and Dysfunction}

Stuart L. Johnson, Saaid Safieddine, Mirna Mustapha and Walter Marcotti

Cold Spring Harb Perspect Med 2019; doi: 10.1101/cshperspect.a033175 originally published online January 7, 2019

\section{Subject Collection Function and Dysfunction of the Cochlea}

Hidden Hearing Loss: A Disorder with Multiple Etiologies and Mechanisms

David C. Kohrman, Guoqiang Wan, Luis Cassinotti, et al.

Hair Cell Afferent Synapses: Function and Dysfunction

Stuart L. Johnson, Saaid Safieddine, Mirna Mustapha, et al.

Active Biomechanics of Sensory Hair Bundles Dolores Bozovic

The Tectorial Membrane: Mechanical Properties and Functions

Jonathan B. Sellon, Roozbeh Ghaffari and Dennis M. Freeman

The Epidemiology of Deafness Abraham M. Sheffield and Richard J.H. Smith

Toward the Optical Cochlear Implant Tobias Dombrowski, Vladan Rankovic and Tobias Moser

Outer Hair Cells and Electromotility Jonathan Ashmore

Interactions between Macrophages and the Sensory Cells of the Inner Ear Mark E. Warchol
Development and Patterning of the Cochlea: From Convergent Extension to Planar Polarity Mireille Montcouquiol and Matthew W. Kelley

Hair-Bundle Links: Genetics as the Gateway to Function

Guy P. Richardson and Christine Petit

Aminoglycoside- and Cisplatin-Induced

Ototoxicity: Mechanisms and Otoprotective

Strategies

Corné J. Kros and Peter S. Steyger

Function and Dysfunction of TMC Channels in Inner Ear Hair Cells

David P. Corey, Nurunisa Akyuz and Jeffrey R. Holt

Cochlear Gene Therapy

Lawrence Lustig and Omar Akil

Age-Related Hearing Loss

Michael R. Bowl and Sally J. Dawson

Inner Ear Connexin Channels: Roles in Development and Maintenance of Cochlear Function Fabio Mammano

A Functional Perspective on the Evolution of the Cochlea Christine Köppl and Geoffrey A. Manley

For additional articles in this collection, see http://perspectivesinmedicine.cshlp.org/cgi/collection/ 